\title{
The cave beetle genus Anthroherpon is polyphyletic; molecular phylogenetics and description of Graciliella n. gen. (Leiodidae, Leptodirini)
}

\author{
Iva Njunjić1, 2,3,7, Michel Perreau ${ }^{4}$, Kasper Hendriks $^{3,5}$, Menno Schilthuizen ${ }^{3,6}$, Louis Deharveng $^{2}$ \\ ${ }^{1}$ Department of Biology and Ecology, University of Novi Sad, Trg Dositeja Obradovića 2, 21000 Novi Sad, Serbia \\ ${ }^{2}$ Muséum National d'Histoire Naturelle, 45 Rue Buffon - CP50, 75005 Paris, France \\ ${ }^{3}$ Naturalis Biodiversity Center, Darwinweg 2, 2333 CR Leiden, The Netherlands \\ ${ }^{4}$ IUT Paris Diderot, Université Paris Diderot, Sorbonne Paris Cité, 5, rue Thomas Mann, 75205, Paris cedex 13, France \\ ${ }^{5}$ Groningen Institute for Evolutionary Life Sciences, University of Groningen, Nijenborg 7, 9747 AG Groningen, \\ The Netherlands \\ ${ }^{6}$ Institute for Tropical Biology and Conservation, Universiti Malaysia Sabah, Jalan UMS, 88400 Kota Kinabalu, \\ Malaysia \\ ${ }^{7}$ E-mail: iva.njunjic@dbe.uns.ac.rs
}

Key words: Coleoptera, convergent evolution, Dinaric Mountains, morphometrics, troglobites

\begin{abstract}
The subtribe Anthroherponina form an iconic group of obligate cave beetles, typical representatives of the Dinaric subterranean fauna, which is considered to be the richest in the world. Phylogenetic studies within this subtribe are scarce and based only on morphological characters, which, due to troglomorphic convergence, are frequently unreliable. Moreover, morphological stasis and morphological polymorphism make classification of taxa difficult. To test if characters that have traditionally been accepted as informative for Anthroherponina classification are indeed reliable, we evaluated the monophyly of the most speciesrich genus of this subtribe - Anthroherpon Reitter, 1889. Our study, based on a molecular phylogenetic analysis of fragments of the 18S, 28S, and COI (both 5' and 3' end) loci revealed that the genus Anthroherpon as conventionally defined is polyphyletic. To resolve this polyphyly, we defined one new additional genus, Graciliella n. gen., for which we then examined the intrageneric diversity using molecular and morphometric approaches. Molecular phylogenetic analysis of two COI mitochondrial gene fragments revealed the presence of four species inside Graciliella n. gen., including two new species, which we here describe as G. kosovaci n. sp. and G. ozimeci n. sp. To analyze interspecific morphological differences within Graciliella we performed a discriminant analysis based on 40 linear morphometric measurements. The results showed that differences between species and subspecies inside Graciliella, however subtle they may seem, are measurable and reproducible. All species of the genus are briefly diagnosed, an identification key is proposed and a distribution map of all taxa of Graciliella is provided.
\end{abstract}

\section{Contents}

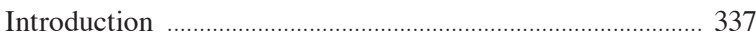

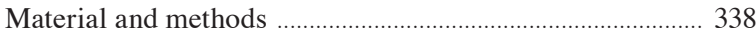

Acronyms ........................................................................... 338

Taxon sampling and morphological study ........................ 339
DNA extraction, PCR amplification, and sequencing .. 339

Phylogenetic analyses ...................................................... 340

Morphometric analysis ........................................................... 340

Results and Discussion .............................................................. 341

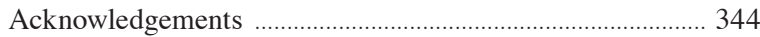

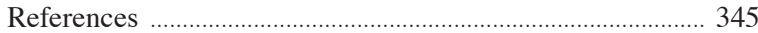

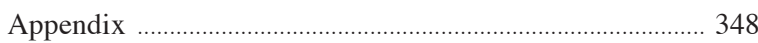

\section{Introduction}

Unrelated organisms that are placed under similar, severe selection pressures often converge on (or evolutionarily remain trapped in) a limited set of body shapes, and may therefore be hard to classify morphologically. Extreme environments (e.g. subterranean habitats, deep sea, polar regions, deserts) exert strong directional selection upon their inhabitants, leading to convergent and generally predictable outcomes (Cloudsley-Thompson, 1988; Trontelj et al., 2012). As a consequence, extremophiles found in Arctic tundra (Grundt et al., 2006), subterranean habitats (Lefébure et al., 2006) and deep-sea environments (Vrijenhoek et al., 1994) are well-known for their morphological uniformity and cryptic diversity.

Subterranean environments are considered to be extreme because of highly stable abiotic conditions and low nutrient availability. Species that have colonized these habitats evolve a somewhat predictable suite of morphological, physiological and behavioural characteristics (Gross, 2012; Trontelj et al., 2012), including eye degeneration, depigmentation, development of sensory organs, longer life cycles, lower metabolic rate, 
and body shape modifications (Racovitza, 1907; Vandel, 1964; Culver et al., 1990; Faille et al., 2009). This set of characteristics is known as 'troglobiomorphy' or 'troglomorphy' and organisms characterized by these features are often restricted to subterranean environment (troglobites).

The troglomorphic phenotype shared by diverse cave-adapted animals is often regarded as a classical example of convergent evolution (Stemmer, 2015). Many studies have shown troglomorphic convergence in different taxa (Christiansen, 1961; Hedin and Thomas, 2010; Protas et al., 2006), which may complicate phylogenetic reconstruction by morphological approaches. Molecular techniques have become a crucial tool to overcome this problem and to efficiently reveal phylogenetic relationships among different taxonomic categories. They have been recently involved in elucidating the phylogeny of different groups with subterranean representatives such as Bivalvia (Stepien et al., 2001), Dytiscidae (Leys et al., 2003), Decapoda (Zakšek et al., 2007), Parabathynellidae (Abrams et al., 2012), Trechini (Faille et al., 2009; 2013) and Leptodirini (Caccone and Sbordoni, 2001; Ribera et al., 2010; Fresneda et al., 2011; Cieslak et al., 2014a; 2014b). Molecular techniques have helped in distinguishing morphological characters inherited from a common ancestor from those resulting from recent, independent adaptation to a specific biotope.

Among Insecta, Coleoptera are the dominant group that have colonized subterranean habitats (Sket, 2005). Two groups of Coleoptera are particularly diverse in caves: the subfamily Cholevinae in the suborder Polyphaga, and the subfamily Trechinae in the suborder Adephaga (Casale et al., 1998; Faille et al., 2009). With more than 230 genera and 900 (mostly polytypic) species, the tribe Leptodirini (Cholevinae) forms one of the most species-rich tribes of cave-adapted Coleoptera, surpassed only by Trechini (Carabidae). Most are subterranean, living in caves and fissures, except a few species inhabiting underground termite nests or superficial litter layers. Within the Leptodirini, four morphological types are recognized: bathyscioid, pholeuonoid, scaphoid, and leptodiroid (Jeannel, 1924). The leptodiroid morphological type, named after Leptodirus hochenwartii Schmidt, 1832 from Slovenia, Croatia, and Italy, is the most derived morphologically, compared to the presumed ancestral body plan (Sket, 2005). Species belonging to this morphological type have extremely long appendages, extremely elongated head and pronotum, hemispherical elytra, and are fully anophthalmic. The subtribe Anthroherponina com- prises taxa of exclusively leptodiroid morphological type, showing the most pronounced troglomorphic characters among Leptodirini (Njunjić et al., 2015). To date, taxonomic studies of Anthroherponina were based exclusively on morphological traits, but possible phenotypic convergence leaves these conclusions doubtful.

To test if characters that have traditionally been accepted as indicative of Anthroherponina classification are indeed reliable, we evaluated the monophyly of the most species-rich genus of this subtribe - Anthroherpon Reitter, 1889. Taxonomy of this genus has always been difficult. Most taxa were described in the late $19^{\text {th }}$ century and in the second half of the $20^{\text {th }}$ century, on a small number of specimens and without an explicit diagnosis, so many were subsequently synonymized. Moreover, the geographical distribution of some taxa is mysteriously disjunct (Njunjić et al., 2015).

The present work provides a first phylogenetic analysis of three closely related genera of the subtribe Anthroherponina: Anthroherpon, Leptomeson Jeannel, 1924, and Hadesia Müller, 1911, combining morphological and molecular approaches. We clarify their generic status and we reveal the existence of the fourth, new genus, Graciliella, for which we then examine the intrageneric diversity. Additionally, two new species belonging to this new genus are described.

\section{Material and methods}

\section{Acronyms}

The following abbreviations for collections and institutions are used: CNHM: Croatian Natural History Museum, Zagreb, Croatia; MNHN: Muséum National d'Histoire Naturelle, Paris, France; Naturalis: Naturalis Biodiversity Center, Leiden, The Netherlands; NMP: Narodni Museum, Prague, Czech Republic; NHM: Naturhistorisches Museum Wien; CINJ: Iva Njunjić Collection, Belgrade, Serbia; CMPR: Michel Perreau Collection, Paris, France; CDPV: Dragan Pavićević Collection, Belgrade, Serbia.

The following abbreviations for morphological details are used: HL: head length (measured from the posterior margin of the clypeus); HW: maximum width of the head; PL: pronotum length (measured along the median line); Pwmax: maximum width of the pronotum (largest transverse width); Pwmin: minimum width of the pronotum (shortest transverse width), PL/ Pwmax: length of the pronotum divided by maximum 
width of the pronotum; MPl: mesothoracic pedunculus length, MPwmin: minimal width of the mesothoracic pedunculus; PL/MPl: length of the pronotum divided by the length of mesothoracic pedunculus; EL: elytra length (as linear distance measured along the median line from the base to the apex); EW: maximum width of the elytra; EL/EW: length of the elytra divided by maximum width of the elytra; MP2/MP3: length of the second maxillary palp divided by the length of the third maxillary palp. Reference to type material is abbreviated as HT: holotype.

\section{Taxon sampling and morphological study}

Specimens were collected in caves of the Dinaric range, in Montenegro, Bosnia and Herzegovina, and Croatia as listed in S1. For amplification and sequencing we used two specimens per population of the genus Graciliella n. gen. and Anthroherpon, and one specimen per population of the genus Hadesia Müller, 1911. Since specimens from the same population had almost identical 28S, 18S and COI gene fragments, we used only one individual per population for the phylogenetic tree. A total of 44 specimens representing 27 taxa from three genera (Anthroherpon, Hadesia, and Leptomeson) were included in the molecular analysis. We chose these genera because they are the most species-rich Anthroherponina and because major taxonomic issues

Table 1. Genera with total number of species and number of species included in the study. Taxonomy follows Perreau (2004), updated.

\begin{tabular}{lrr}
\hline Genus & N. spp. & Sampled spp. \\
\hline Anthroherpon & 30 & 18 \\
Hadesia & 4 & 4 \\
Leptomeson & 9 & 4 \\
\hline
\end{tabular}

need to be resolved among them. As outgroups we chose several subterranean species or subspecies from other genera of the tribe Leptodirini: Parapropus sericeus muelleri Jeannel, 1924, Charonites Apfelbeck, 1907 sp., and Apholeuonus nudus sturanyi Apfelbeck, 1906 of which we sequenced a single individual per population. To root the tree, we used Speonesiotes Jeannel, $1910 \mathrm{sp}$. belonging to the subtribe Bathysciotina. In total we sampled 36 specimens of 18 species of Anthroherpon, 4 specimens of 4 species of Hadesia, and 4 specimens of 4 species of Leptomeson (Table 1; S1).

After extraction, male genitalia were cleared in clove oil, mounted in Euparal on glass slides and pinned beneath the specimens. The external morphology of specimens was examined using Leica MZ 75 and Leica M10 stereomicroscopes. Microphotographs were taken on a Leica DIAPLAN or a Zeiss AXIOLAB microscope with a camera diagnostic instrument Spot INSIGHT IN1820. Macrophotographs were taken using a Canon Eos 70D camera with Canon EF MP-E $65 \mathrm{~mm} \mathrm{f} / 2.8$ macro lens and Canon macro twin lite $\mathrm{mt}-24 \mathrm{ex}$ flash. Digital pictures were processed using the Helicon Focus software 5.3 (http://www.heliconsoft.com/heliconsoft-products/helicon-focus/).

\section{DNA extraction, PCR amplification, and sequencing}

The specimens used in the study were collected alive in the field and preserved in $96 \%$ ethanol. DNA was extracted from whole specimens or from one leg with a standard phenol-chloroform extraction (Blin and Stafford, 1976) or the DNeasy Tissue Kit (Qiagen GmbH, Hilden, Germany). Voucher specimens are stored in the MNHN (Paris, France), CNHM (Zagreb, Croatia) and DNA aliquots are kept in the tissue collections of Naturalis (Leiden, Netherlands).

We amplified fragments of two nuclear genes: 5' end of the small ribosomal unit, 18S rRNA (SSU) and

Table 2. Primers used in the study.

\begin{tabular}{|c|c|c|c|c|}
\hline Fragment & Name & Sense & Sequence 5'-3' & Reference \\
\hline COIa & LCOI-1490 & $\mathrm{F}$ & GGTCAACAAATCATAAAGATATTG & Folmer et al. (1994) \\
\hline COIa & HCOI-2198 & $\mathrm{R}$ & TAAACTTCAGGGTGACCAAAAAATCA & Folmer et al. (1994) \\
\hline $\mathrm{COIb}$ & Jerry & $\mathrm{F}$ & CAACATTTATTTTGATTTTTTGG & Simon et al.(1994) \\
\hline$C O I b$ & Pat & $\mathrm{R}$ & TCCAATGCACTAATCTGCCATATTA & Simon et al.(1994) \\
\hline $18 S$ & 5 & $\mathrm{~F}$ & GACAACCTGGTTGATCCTGCCAGT & Shull et al. (2001) \\
\hline $18 S$ & b5.0 & $\mathrm{R}$ & TAACCGCAACAACTTTAAT & Shull et al. (2001) \\
\hline $28 S$ & $\mathrm{Ka}$ & $\mathrm{F}$ & ACACGGACCAAGGAGTCTAGCATG & Ribera et al. (2010) \\
\hline $28 S$ & $\mathrm{~Kb}$ & $\mathrm{R}$ & CGTCCTGCTGTCTTAAGTTAC & Ribera et al. (2010) \\
\hline
\end{tabular}


an internal fragment of the large ribosomal unit, $28 \mathrm{~S}$ rRNA (LSU), and of two non-overlapping sections of mitochondrial gene fragments-the 5' and 3' halves of cytochrome c oxidase subunit 1 (which we here term COIa and COIb, respectively). Primers used are given in Table 2, and PCR protocols are given in S2. Sequences were assembled and edited using Geneious version 8.0.5 (http://www.geneious.com/, Kearse et al., 2012). DNA sequences obtained for each genetic marker were aligned separately using MAFFT version 7 (Katoh and Standley, 2013). Sequences have been deposited in GenBank with Acc. Nos (S1).

\section{Phylogenetic analyses}

For each sequence alignment, the optimal model of nucleotide substitution was determined using jModelTest2 (Darriba et al., 2012; Guindon and Gascuel, 2003), run on the CIPRES webportal (Miller et al., 2010). Selection was based on the Akaike Information Criterion (AIC), and resulted in selection of TIM2ef+I, GTR+G, TPM1uf+I+G and TPM3uf $+\mathrm{I}+\mathrm{G}$ substitution models for $18 \mathrm{~S}, 28 \mathrm{~S}$, COIa and COIb, respectively. We did two separate phylogenetic analyses - one at the genus level, using all three loci, and one at the species level within Graciliella using only COI. Phylogenetic analysis was performed using MrBayes 3.2.2 (Ronquist and Huelsenbeck, 2003) on CIPRES (Miller et al., 2010), with settings for multiple markers unlinked, running two replicates of $15 \times 10^{6}$ generations each. Sample frequency was set to 5000 . Convergence diagnostics were run using Tracer version 1.5 (Rambaut et al., 2014), where ESS values for all parameters were $>>200$. After discarding a $25 \%$ burn-in, the resulting majority-rule consensus tree was visualized using FigTree version 1.4 (Rambaut, 2012).

\section{Morphometric analysis}

We subjected a total of 41 individuals, all males, belonging to G. apfelbecki apfelbecki (14 specimens), $G$. apfelbecki scutulatum (1 specimen), G. metohiensis (14 specimens), G. absoloni (1 specimen), G. lahneri (2 specimens), G. ozimeci (9 specimens), and G. kosovaci (1 specimen) to linear morphometric measurement with a Micro-Vu Vertex 251HC (https://www.

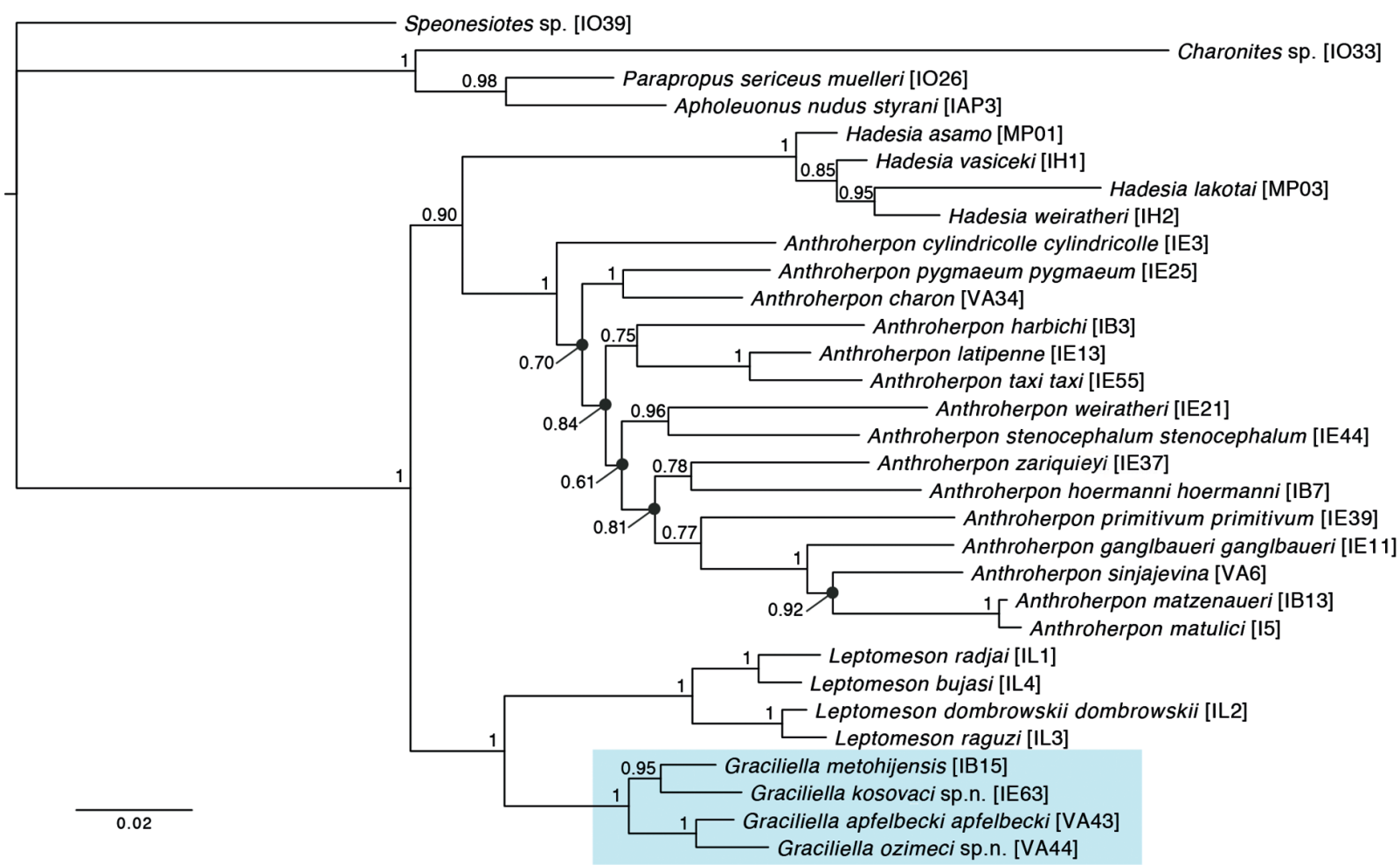

Fig 1. Bayesian inference of combined 18S, 28S, COIa, and COIb data sets for Hadesia, Anthroherpon, Leptomeson, and Graciliella. Numbers above nodes are posterior probabilities. 
microvu.com/), three-dimensional set-up, using Inspec Metrology Software (https://www.inspec-inc.com/). We used 40 landmarks on antennae, maxillary palps, head, thorax, abdomen, and legs. Each individual was measured three times. In a small number of cases, obvious measurement errors were detected a posteriori (values differing by a factor of $>2$ from the other two replicates of the same individual). These were then replaced by the average value of the other two replicates. The full list of measured material and their respective morphometrics is given in S3 and S5; the derivations of the 40 linear measurements are given in S4. We first checked, for those species for which we had DNA extracts, whether the species that had been recognized by traditional, qualitative morphological study, could also be recovered as monophyletic groups in the molecular phylogeny (see below). As this appeared to be the case, we then subjected this set of independently obtained quantitative measurements to a Discriminant Analysis in PAST 3.10 (Hammer et al., 2001), to investigate whether a more objective morphometric analysis would allow us to recognize the same groups.

\section{Results and Discussion}

Our study, based on morphological and molecular approaches, reveals that the genus Anthroherpon as conventionally defined (Jeannel, 1924; Guéorguiev 1990; Giachino and Gueorguiev, 1993; Giachino and Vailati, 2005; Perreau and Pavićević, 2008) is polyphyletic (Fig. 1). The genus Leptomeson forms the highly supported sister clade of one polytypic Anthroherpon species, namely A. apfelbecki sensu lato and the genus Hadesia forms the sister clade of the remaining Anthroherpon species. To resolve this polyphyly, we defined one new additional genus, Graciliella, comprising A. apfelbecki sensu lato and one species, A. absoloni (Guéorguiev, 1990), for which we did not have genetic data, but which morphologically closely resembles A. apfelbecki (see below under the genus description). Morphological phylogenetic analysis of the species of Hadesia was obtained by Perreau and Pavićević (2008). Their parsimony analysis gave a well-supported monophyletic group for $H$. vasiceki Müller, 1911 and H. lakotai Perreau and Pavićević, 2008 (bootstrap value $100 \%$ ), but the possible sister group Hadesia asamo Perreau and Pavićević, $2008+$ $H$. weiratheri Zariquiey, 1927 was weakly supported (bootstrap value $50 \%$ ). However, analysis based on distances as optimality criterion supported both groups: H. vasiceki $+H$. lakotai and $H$. asamo $+H$. weiratheri as sister groups at the same level of bootstrap value (Perreau and Pavićević, 2008). Our phylogenetic tree based on molecular data has a different topology $-H$. asamo and $H$. vasiceki are early-branching and $H$. lakotai and $H$. weiratheri are forming a clade. These results are surprising regarding the distribution of the species. Namely, H. asamo and $H$. weiratheri are both located in the Orjen massif in Montenegro while $H$. weiratheri and $H$. lakotai were found in remote massifs, in caves which are more than $50 \mathrm{~km}$ apart. Moreover, H. asamo and H. weiratheri are morphologically extremely similar (Perreau and Pavićević, 2008) which can easily mislead phylogenetic reconstruction by morphological approaches.

The genus Leptomeson was originally established as a subgenus of Anthroherpon (Jeannel, 1924) and then subsequently raised to genus rank by Guéorguiev (1990). This separation was based on the following characters of Leptomeson: more developed mesothoracic pedunculus, with constriction in the middle part and wider in the base, endophallus with differentiated basal 'armature' (sclerified stylet-shaped phanera, Giachino et al., 2011) and parameres bearing 4 setae. Further investigations and discoveries of several new species belonging to this genus have shown that number of setae on parameres varies in fact from 3 to 4 (Giachino et al., 2011). The molecular phylogenetic reconstruction is in accordance with the morphology regarding the separation of the genus Leptomeson from Anthroherpon. The clade Graciliella + Leptomeson, in addition to being clearly supported by the molecular analysis, is also morphologically supported by the following characters that are likely synapomorphies: very elongated pronotum and mesothoracic pedunculus, and mesoventrum without processus between mesocoxae. Mesoventral processus is normally entire (it completely separates the two mesocoxal cavities) in Leptodirini, except in some highly evolved groups such as Anthoherponina in which it is reduced or absent (Jeannel, 1911). We observed that the degree of reduction of this processus is a distinguishing character among Anthroherponina: it is present in the genus Anthroherpon, and absent in Leptomeson and Graciliella. However, this character is still insufficiently explored in other Anthroherponina to assess its relevance in non-Anthroherponine Leptodirini. For instance, $A n$ throherpon stenocephalum (Apfelbeck, 1910) is the only species of the genus Anthroherpon in which we noticed intrapopulation variability of this character: some specimens have a mesoventral processus between 


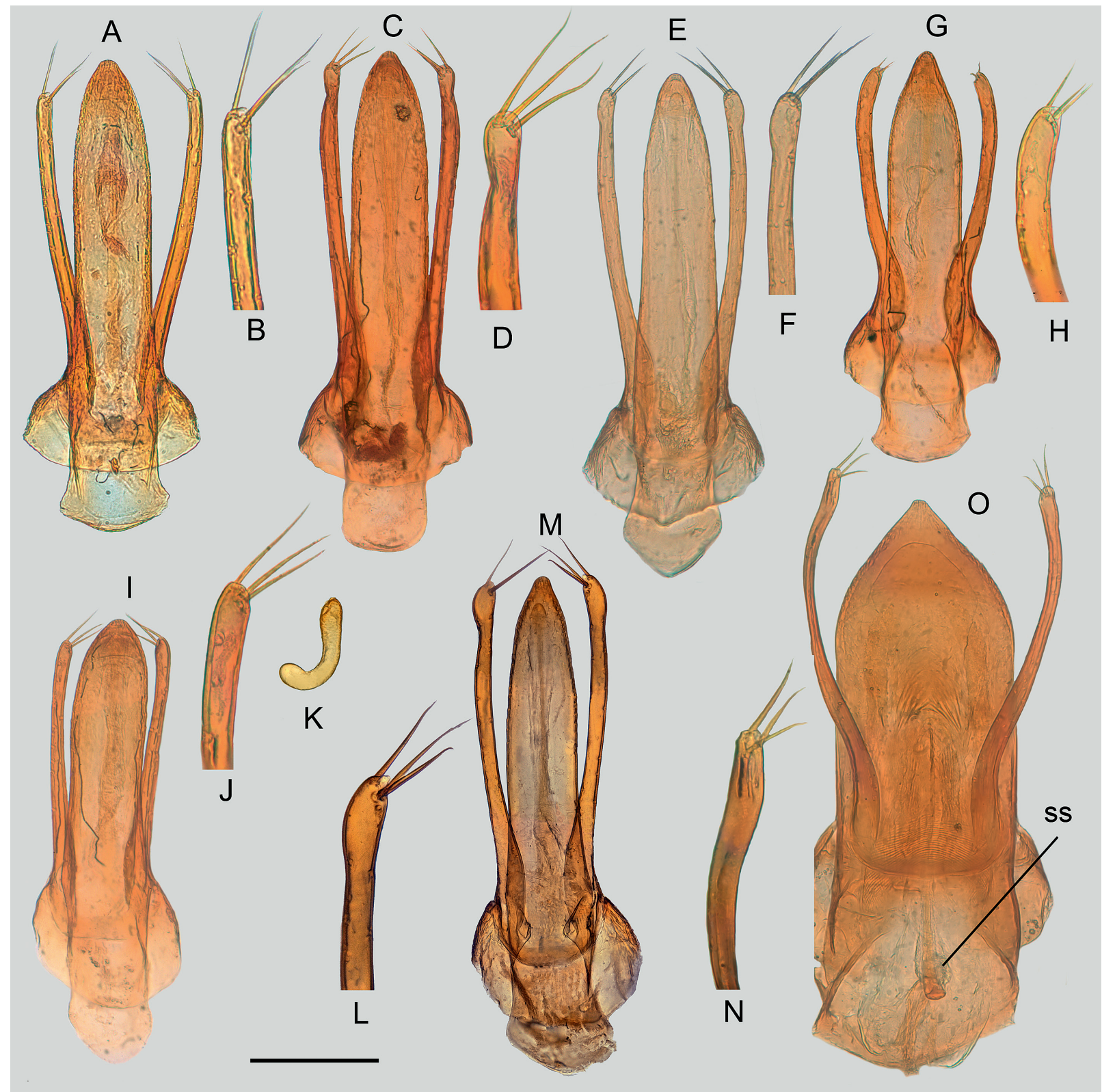

Fig. 2. Genital structures of Graciliella and Leptomeson, complete aedeagus + detail of paramere apex: A-B. G. apfelbecki apfelbecki; C-D. G. metohijensis; E-F. G. absoloni; G-H. G. kosovaci sp. n.; I-J. G. ozimeci sp. n.; L-M. G. lahneri; N-O. L. leonhardi; ss. sclerified structure in the endophallus; K. spermatheca of G. ozimeci sp. n. Scale bar is $0.1 \mathrm{~mm}$

the mesocoxae while it is absent in others, but no intermediate state was observed. The monophyly of the genus Leptomeson is morphologically supported by the presence of the sclerotized structures in the endophallus (Fig. 2O), which are absent in Graciliella, and the shape of mesothoracic pedunculus with the constriction in the mid-section or posterior of the mid-section (Fig. 3C).
A dorsal comb of very short bristles on the terminal maxillary palpomere is present in three genera that we analyzed in this study (Anthroherpon, Leptomeson, and Graciliella). However, it is absent in Hadesia. We could find no previous literature regarding this character so that we believe it was not previously observed. Given the scarcity of nutrients in the subterranean 


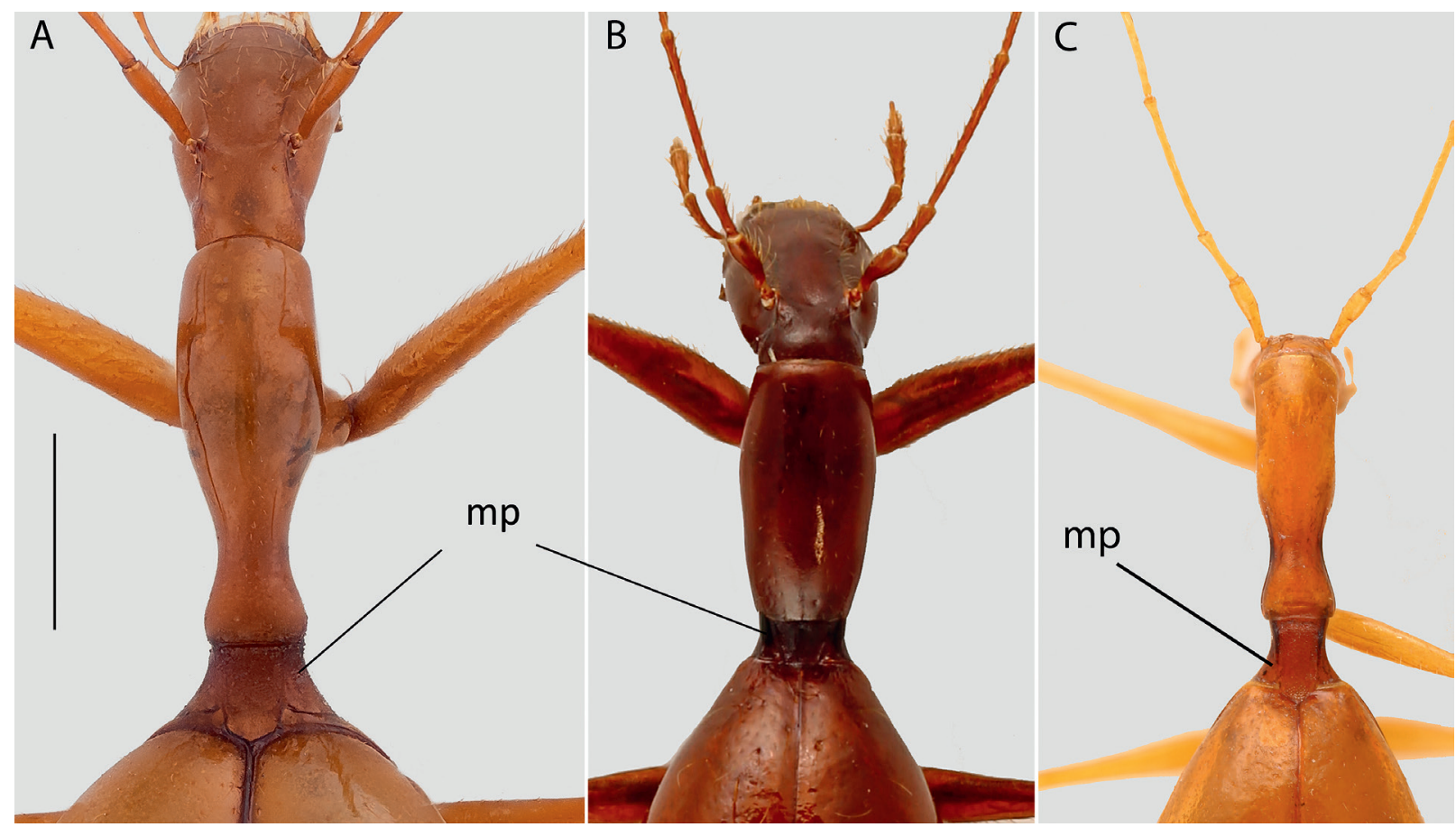

Fig. 3. Pronotum and mesothoracic pedunculus: A. Graciliella metohijensis; B. Anthroherpon cylindricolle cylindricolle; C. Leptomeson bujasi; mp. mesothoracic pedunculus. Scale bar is $1 \mathrm{~mm}$.

environment, this comb is possibly an extra sensory organ that has a yet to be determined role in detecting food.

Our molecular analysis shows that the four Graciliella species are genetically well-separated, with COIdifferences between 3.9 and $12.4 \%$, values that are normally found at or above the species level in Cholevinae (Schilthuizen et al., 2011) (Fig. 4). To confirm that our mostly genetically circumscribed species indeed correspond with morphologically recognizable units, we carried out a linear discriminant analysis (LDA) based on 40 linear morphometric measurements. An LDA is especially suited for maximizing inter-group separation and minimizing intra-group separation for pre-defined units (McLachlan, 2004). This LDA confirmed that the interspecific morphological differences, however subtle and minute as they may seem, are measurable and reproducible. Along the first two axes (with major loadings for tibia lengths, lengths of antennomeres 4 and 11, and elytra length), all species can be distinguished, except the two new species, G. kosovaci and G. ozimeci (Fig. 5A). These latter two species, however, are well-separated along the third discriminant axis, in which there are additional loadings for the first meso- and metatarsomere
(Fig. 5B). Based on this independent, initial morphometric separation, we then detected additional qualitative diagnostic characters in setation, shape of pronotum, aedeagus, and microsculpture. The diagnoses and identification keys are largely based on these qualitative characters, as they are more easily accessible.

Perreau and Pavićević (2008) reconstructed the phylogeny of the subtribe Anthroherponina based on 11 morphological characters. Their most parsimonious tree shows Leptomeson and Anthroherpon as sister genera, and Hadesia distantly related, as sister genus of Kircheria Giachino and Vailati (2006). The character states that Perreau and Pavićević defined for Anthroherpon also apply to all species of Graciliella. If we rather accept our molecular phylogeny, in which Graciliella is a sister clade of Leptomeson, and Anthroherpon s.str. sister clade of Hadesia, this would imply that a large number of morphological characters are strongly homoplasious. These characters are: female ventrite VIII with an anterior apophysis versus without, aedeagus with internal sclerified structure versus without, abdominal ventrites with glabrous plates versus without glabrous plates, female first ventrite with lateral hollows versus without, third maxillary palpomere short versus long, claws narrow versus wide. Although 


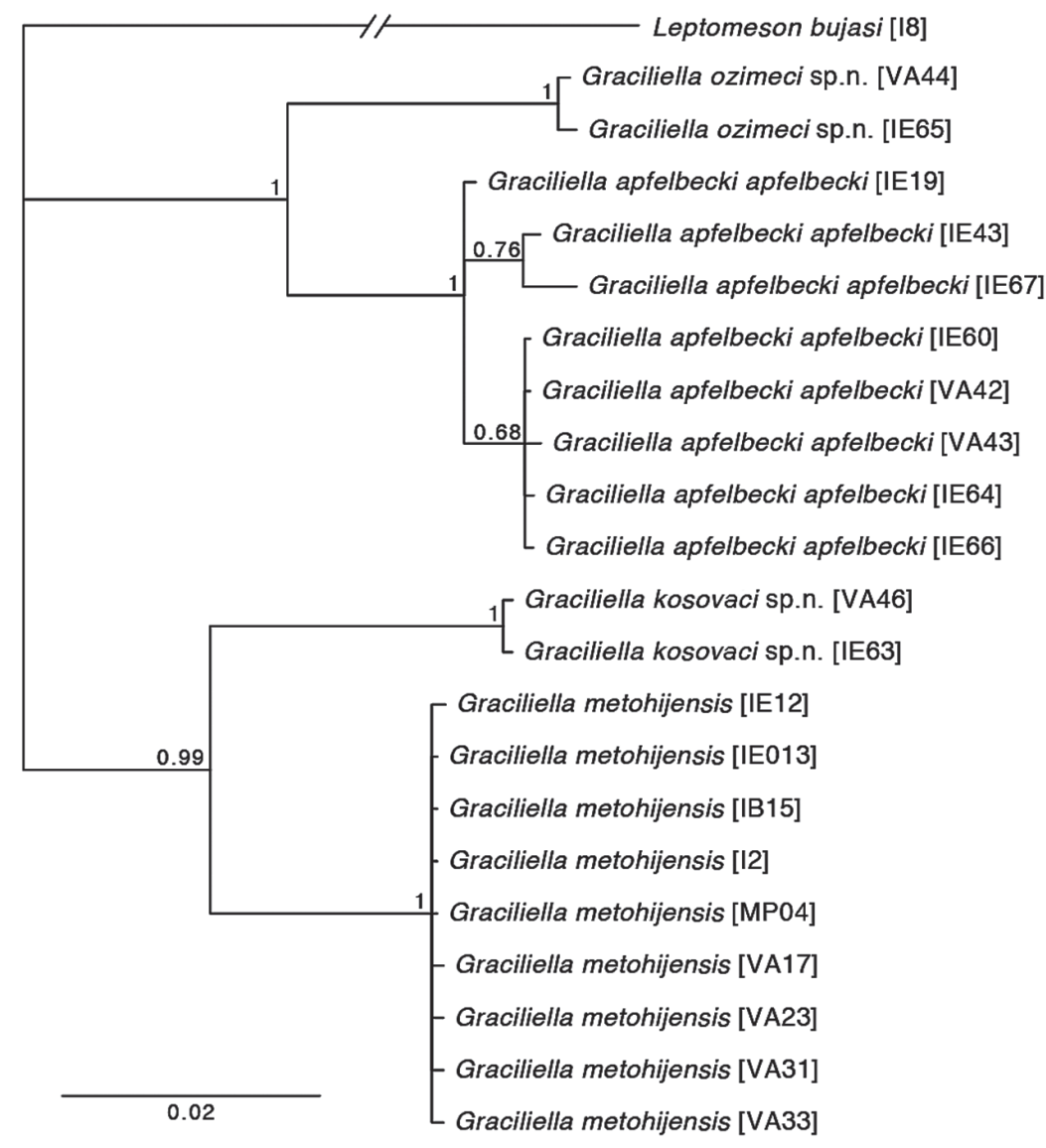

Fig. 4. Bayesian inference of combined COIa and COIb data sets for Graciliella. Numbers above nodes are posterior probabilities.
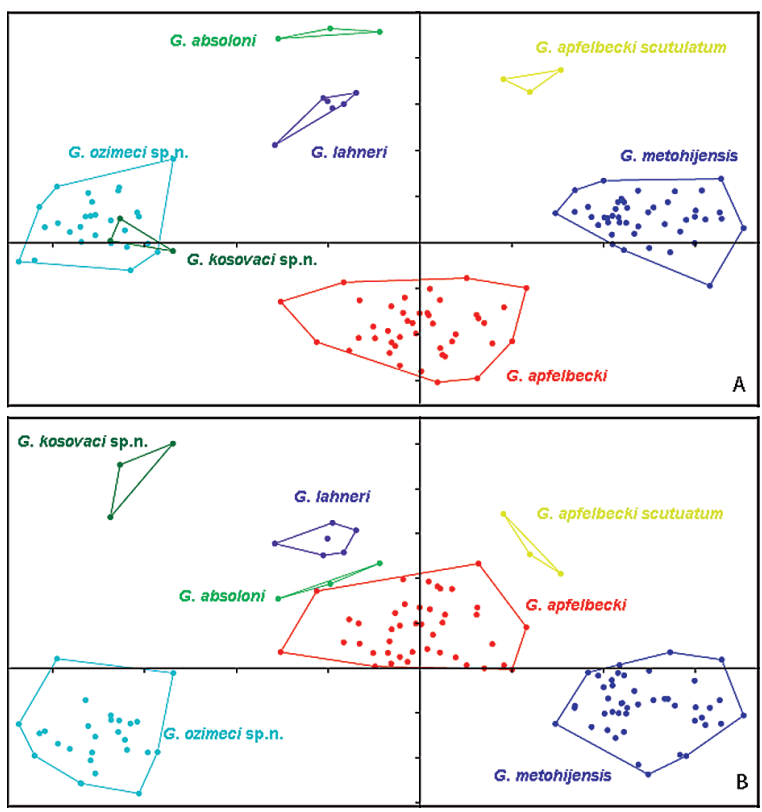

Fig. 5. Linear discriminant analysis (LDA) based on 40 linear morphometric measurements. A. Axes 1 and 2; B. Axes 1 and 3. many of these characters seem reliable and have traditionally been accepted as indicative of Anthroherponina classification, our results suggest that perhaps this could be attributed to convergence due to shared selective pressures rather than to shared ancestry.

\section{Acknowledgements}

We warmly thank Petra Bregović (Croatian Biospeleological Society), Branko Jalžić (CNHM), Thierry Deuve (MNHN), Eric Quéinnec (UPMC), Pier Mauro Giachino (CGi), Jiří Hájek (NMP), and Harald Schilhammer (NHM) for providing many specimens from their institution or their private collections. Special thanks to Roman Ozimec (Croatian Biospeleological Society) for collecting two new species and providing many specimens of the genus Anthroherpon, to speleologists Petar Kosovac (Penjački Klub AS, Belgrade), Željko Madžgalj (Centar za istrazivanje i zastitu krša, Montenegro), Jasminko Mulaomerović and Una Tulić (both from Bosnia and Herzegovina) for their help in the field and in collecting samples. We are very grateful to Nenad Grković, Dubravko Kurtović, Predrag Milošević, and Vanja Kukurić, all members of the speleological society Zelena Brda, Trebinje (Bosnia and Herzegovina), and to 
Ivo Karaman and Marjan Komnenov (both from University of Novi Sad, Serba) for their help during the field. We also thank to the municipality of Ravno (Bosnia and Herzegovina) for giving us permission to collect in Vjeternica and to Nikša Vuletić for his help in the field. We are particularly grateful to Dragan Pavićević (Institute for Nature Conservation of Serbia) for his long-term help on working on cave beetles and to Michel Baylac (MNHN) and Thibaut De Meulemeester (Naturalis) for their help regarding morphometrics. Finally, we would like to thank the following staff from Naturalis: Marcel Eurlings, Kevin Beentjes, Frank Stokvis, Sofia Fernandes Gomes, and students of Hogeschool van Amsterdam Steven Visser and Wesley van Oostenbrugge for providing their help during the lab work. This study has been partly funded by the ATM 'formes' of MNHN and the French government $\mathrm{PhD}$ scholarship grants via Campus France. Part of the work was obtained during the Martin Fellowship of the first author in Naturalis Biodiversity Center.

\section{References}

Abrams MK, Guzik TM, Cooper BJS, Humphreys FW, King AR, Cho LJ, Austin DA. 2012. What lies beneath: Molecular phylogenetics and ancestral state reconstruction of the ancient subterranean Australian Parabathynellidae (Syncarida, Crustacea). Molecular Phylogenetics and Evolution 64: 130-144. doi: 10.1016/j.ympev.2012.03.010

Apfelbeck V. 1911. Contributiones ad Coleopterum faunam peninsulae balcanicae. Glasnik Zemaljskog Muzeja u Bosni i Hercegovini 23: 209-223.

Apfelbeck V. 1916. Fauna insectorum balcanica. VI. 1. Beschreibung von 27 neuen Coleopteren der Balkanhalbinsel. Wissenschaftliche Mitteilungen aus Bosnien und der Herzegowina 13: 339-353.

Beutel GR, Leschen ABR. 2016. Coleoptera, Beetles. Morphology and Systematics. Berlin/Boston, De Gruyter.

Caccone A, Sbordoni V. 2001. Molecular biogeography of cave life: A study using mitochondrial DNA from Bathysciine beetles. Evolution 55: 122-130.

Christiansen KA. 1961. Convergence and parallelism in cave Entomobryinae. Evolution 15: 288-301.

Cieslak A, Fresneda J, Ribera I. 2014a. Life-history specialization was not an evolutionary dead-end in Pyrenean cave beetles. Proceedings of the Royal Society B 281: 20132978. http://dx.doi.org/10.1098/rspb.2013.2978

Cieslak A, Fresneda J, Ribera I. 2014b. Developmental constraints in cave beetles. Biology letters 10: 20140712. http:// dx.doi.org/10.1098/rsbl.2014.0712

Cloudsley-Thompson JL. 1988. Evolution and adaptation of terrestrial arthropods. Springer $141 \mathrm{p}$.

Culver DC, Kane TC, Fong DW, Jones R, Taylor MA, Sauereisen SC. 1990. Morphology of cave organisms. Is it adaptive? Mémoires de Biospéologie 17: 13-26.

Cvitanović H. 2015. Katastar speleoloških objekata, podzemnih građevina, krških izvora i krških bunara kopnenog dijela Dubrovačko-neretvanske županije. Spelaeologia ragusina 1, 13: 1-152.

Darriba D, Taboada GL, Doallo R, Posada D. 2012. jModelTest 2: more models, new heuristics and parallel computing. $\mathrm{Na}$ ture methods 9: 772-772. doi: 10.1038/nmeth.2109
Deuve T. 2001. The epipleural field in hexapods. Annales de la Société Entomologique de France (Nouvelle série) 37: 195-231.

Faille A, Ribera I, Deharveng L, Bourdeau C, Garnery L, Quéinnec E, Deuve T. 2009. A molecular phylogeny shows the single origin of the Pyrenean subterranean Trechini ground beetles (Coleoptera: Carabidae). Molecular Phylogenetics and Evolution 54: 93-106. doi: 10.1016/j.ympev.2009.10.008

Faille A, Casale A, Balke M, Ribera I. 2013. A molecular phylogeny of Alpine subterranean Trechini (Coleoptera: Carabidae). BMC Evolutionary Biology 13: 248. doi: 10.1186/ 1471-2148-13-248

Fresneda J, Grebennikov V, Ribera I. 2011. The phylogenetic and geographic limits of Leptodirini (Coleoptera: Leiodidae: Cholevinae), with a description of Sciaphyes shestakovi sp. n. from the Russian Far East. Arthropods Systematics \& Phylogeny 69: 99-123.

Folmer O, Black M, Hoeh W, Lutz R, Vrijenhoek R. 1994. DNA primers for amplification of mitochondrial cytochrome c oxidase subunit I from diverse metazoan invertebrates. Molecular marine biology and biotechnology 3: 294-299.

Giachino PM, Bregović P, Jalžić B. 2011. Five new species of the genus Leptomeson Jeannel, 1924 from Croatia and Bosnia and Herzegovina (Coleoptera, Cholevidae, Leptodirinae). Natura Croatica 20: 355-374.

Giachino PM, Guéorguiev VB. 1993. Note sul genere Antroherpon Reitter (Coleoptera Cholevidae Leptodirinae). Annali del Museo civico di Storia naturale di Brescia 28: 287-329.

Giachino PM, Vailati D. 2005. Nuovi dati sul genere genere Anthroherpon Reitter, 1889 (Coleoptera Cholevidae Leptodirinae). Bollettino del Museo civico di Storia Naturali di Venezia 29: 149-163.

Gross JB. 2012. Cave Evolution. In: eLS. John Wiley \& Sons Ltd, Chichester. http://www.els.net [doi: 10.1002/978047001 5902.a0023628]

Grundt HH, Kjølner S, Borgen L, Rieseberg LH, Brochmann C. 2006. High biological species diversity in the arctic flora. Proceedings of the National Academy of Sciences of the United States of America 103: 972-975. doi: 10.1073/pnas. 0510270103

Guéorguiev VB. 1990. Recherches sur les Bathysciinae (Coleoptera: Catopidae) de Yougoslavie. I. Antroherponini. Acta Entomologica Musei nationalis Pragae 42: 37-273.

Guindon S, Gascuel O. 2003. A simple, fast, and accurate algorithm to estimate large phylogenies by maximum likelihood. Systematic Biology 52: 696-704. doi: 10.1080/1063515 0390235520

Hajna ZN. 2012. Dinaric karst: Geography and geology. Pp. 195-203 in: Culver DC, White WB, eds, Encyclopedia of Caves. Amsterdam: Elsevier Academic Press, $2^{\text {nd }}$ edition. doi: 10.1016/B978-0-12-383832-2.00028-1

Hammer $\varnothing$, Harper DAT, Ryan PD. 2001. PAST: Paleontological statistics software package for education and data analysis. Paleontologia Electronica 4: 1-9.

Hedin M, Thomas MS. 2010. Molecular systematics of eastern North American Phalangodidae (Arachnida: Opiliones: Laniatores), demonstrating convergent morphological evolution in caves. Molecular Phylogenetics and Evolution 54: 107-121. doi: 10.1016/j.ympev.2009.08.020

Jeannel R. 1911. Revision des Bathysciinae (Coléopteres Silphides). Archives de Zoologie expérimentale et générale 5: 1-641. 
Jeannel R. 1914. Coleopterorum catalogus, Silphidae: Subfam. Bathysciinae. Pars 60. Berlin: W. Junk.

Jeannel R. 1924. Monographie des Bathysciinae. Archives de Zoologie expérimentale et générale 63: 1-436.

Jeannel R. 1930. Révision des genres Blattochaeta et Antroherpon (Bathysciinae). L'Abeille 34: 123-148.

Katoh K, Standley DM. 2013. MAFFT multiple sequence alignment software v 7: improvements in performance and usability. Molecular Biology and Evolution 30: 772-780. doi: 10.1093/molbev/mst010

Kearse M, Moir R, Wilson A, Stones-Havas S, Cheung M, Sturrock S, Buxton S, Cooper A, Markowitz S, Duran C, Thierer T, Ashton B, Mentjies P, Drummond A. 2012. Geneious Basic: an integrated and extendable desktop software platform for the organization and analysis of sequence data. Bioinformatics 28: 1647-1649.

Lefébure T, Douady JC, Gouy M, Trontelj P, Briolay J, Gibert J. 2006. Phylogeography of a subterranean amphipod reveals cryptic diversity and dynamic evolution in extreme environments. Molecular Ecology 15: 1797-1806. doi: 10.1111/j.1365 -294X.2006.02888.x

Leys R, Watts C, Cooper SJB, Humphreys WF. 2003. Evolution of subterranean diving beetles (Coleoptera: Dytiscidae: Hydroporini, Bidessini) in the arid zone of Australia. Evolution 57: 2819-2834. doi: 10.1111/j.0014-3820.2003.tb01523.x

Matcha J. 1916. Antroherpon Lahneri n. sp. Koleopterologische Rundschau 5: 63.

McLachlan GJ. 2004. Discriminant analysis and statistical pattern recognition. Wiley-Interscience.

Miller MA, Pfeiffer W, Schwartz T. 2010. Creating the CIPRES Science Gateway for inference of large phylogenetic trees. In: Proceedings of the Gateway Computing Environments Workshop (GCE), 14 Nov. 2010. New Orleans, Louisiana 2010: 1-8. doi: $10.1145 / 2016741.2016785$

Müller G. 1910. Diagnosen neuer Höhlensilphiden. Zoologischer Anzeiger 36: 184-186.

Njunjić I, Perreau M, Pavićević D. 2015. Two new species of the genus Anthroherpon Reitter, 1889 from northern Montenegro with notes on the 'A. ganglbaueri' species group (Coleoptera: Leiodidae: Cholevinae: Leptodirini). Zootaxa 3915: 403-412.

Perreau M. 2004. Family Leiodidae Fleming, 1821. Pp. 133-203 in: Löbl I, Smetana, eds, Catalogue of Palaearctic Coleoptera, Vol. 2: Hydrophiloidea - Histeroidea - Staphylinoidea. Apollo Books, Steenstrup.

Perreau M, Pavićević D. 2008. The genus Hadesia Müller, 1911 and the phylogeny of Anthroherponina (Coleoptera, Leiodidae, Cholevinae, Leptodirini). Pp. 215-239 in: Pavićević, D, Perreau M, eds, Advances in the studies of the fauna of the Balkan Peninsula. Papers dedicated to the memory of Guido Nonveiller. Institute for Nature Conservation of Serbia, monographs 22.

Pretner E. 1974. Zasluge Leona Weiratheria-ja za jugoslavansko Biospeleologijo. Acta entomologica Jugoslavica 10: 7-13.

Protas EM, Hersey C, Kochanek D, Zhou Y, Wilkens H, Jeffery RW, Zon IL, Borowsky R, Tabin JC. 2006. Genetic analysis of cavefish reveals molecular convergence in the evolution of albinism. Nature Genetics 38: 107-111. doi: 10.1038/ng 1700

Racovitza EG. 1907. Essai sur les problèmes biospéologiques. Archives de Zoologie expérimentale et générale 6: 371-488.

Rambaut A. 2012. FigTree v1.4. http://tree.bio.ed.ac.uk/software/ figtree/
Rambaut A, Suchard M, Xie D, Drummond A. 2014. Tracer v1.6. http://tree.bio.ed.ac.uk/software/tracer/

Remy P. 1940. Sur le mode de vie des Hadesia dans la grotte Vjetrenica (Col.Bathysciinae). Revue française d'Entomologie, 7: 1-8.

Ronquist F, Huelsenbeck JP. 2003. MrBayes 3: Bayesian phylogenetic inference under mixed models. Bioinformatics 19: 15721574. doi: 10.1093/bioinformatics/btg180

Schilthuizen M, Scholte C, Wijk REJ, Dommershuijzen J, Horst D, Schlochtern MM, Lievers R, Groenenberg D. 2011. Using DNA-barcoding to make the necrobiont beetle family Cholevidae accessible for forensic entomology. Forensic Science International 210: 91-95. doi: 10.1016/j.forsciint. 2011.02.003

Shull VL, Vogler AP, Baker MD, Maddison DR, Hammond PM. Sequence alignment of $18 \mathrm{~S}$ ribosomal RNA and the basal relationships of adephagan beetles: evidence of monophyly of aquatic families and the placement of Trachypachidae. Systematic Biology 50: 945-969. doi: 10.1080/10635150 1753462894

Simon C, Frati F, Beckenbach A, Crespi B, Liu H, Flook P. 1994. Evolution, weighting and phylogenetic utility of mitochondrial gene sequences and a compilation of conserved polymerase chain reaction primers. Annals of the Entomological Society of America 87: 651-701. doi: http://dx.doi.org/10.1093/ aesa/87.6.651

Sket B. 2004. The cave hygropetric - a little known habitat and its inhabitants. Archiv für Hydrobiologie 160: 413-425.

Sket B. 2005. Dinaric karst, diversity in. Pp. 158-165 in: Culver DC, White WB, eds, Encyclopedia of Caves. Amsterdam: Elsevier Academic Press.

Stemmer M, Schuhmacher NL, Foulkes SN, Bertolucci C, Wittbrodt J. 2015. Cavefish eye loss in response to an early block in retinal differentiation progression. Development 142: 743-52. doi: 10.1242/dev.114629

Stepien CA, Morton B, Dabrowska AK, Guarnera AR, Radja T, Radja B. 2001. Genetic diversity and evolutionary relationships of the troglodytic 'living fossil' Congeneria kusceri (Bivalvia: Dreissenidae). Molecular Ecology 10: 1873-1879.

Trontelj P, Blejec A, Fišer C. 2012. Ecomorphological convergence of cave communities. Evolution 66-12: 3852-3865. doi: 10.1111/j.1558-5646.2012.01734.x

Vandel A. 1964. Biospéologie. La Biologie des Animaux Cavernicoles. Gauthier-Villars, Paris.

Vrijenhoek RC, Schutz JS, Gustafson GR, Lutz AR. 1994. Cryptic species of deep sea clams (Mollusca, Bivalvia, Vesicomyidae) from hydrothermal vent and cold water seep environments. Deep-Sea Research Part I 41: 1171-1189. doi: 10.1016/09670637(94)90039-6

Winkler A. 1925. Ergebnisse von Exkursionen auf Blindkäfer in der südlichen Herzegowina. Koleopterologische Rundschau 11: 137-148.

Zakšek V, Sket B, Trontelj P. 2007. Phylogeny of the cave shrimp Troglocaris: evidence of a young connection between Balkans and Caucasus. Molecular Phylogenetics and Evolution 42: 223-235. doi: 10.1016/j.ympev.2006.07.009

Zariquiey R. 1927. Nuevos Antroherpon (Col. Silph.) (Nota preliminar). Butlletí de l'Institució Catalana d'Història natural 27: 159-163.

Received: 29 March 2016

Revised and accepted: 13 June 2016

Published online: 30 August 2016

Editor: J.C. Biesmeijer 


\section{Online supplementary information}

S1. Sequenced specimens, with depository, locality, collectors, and sequence accession numbers.

S2. PCR cycling conditions.

S3. The list of material included in the morphometric analysis (Sheet 1) and list of measured traits (Sheet 2).

S4. The derivations of the 40 linear measurements.

S5. Landmarks recorded on the body of Graciliella spp. 


\section{Appendix}

\section{Systematic part}

Above, where we discuss the results of molecular phylogenetics, we show that the genus Anthroherpon is polyphyletic. For this reason we erect a new genus, Graciliella. In this systematic section, we describe and diagnose this genus and its constituent species. For full treatment of molecular phylogenetics we refer to the Results section.

http://zoobank.org/urn:lsid:zoobank.org:pub: 0A49048 5-E40F-4422-8D34-D78A92716FB0

\section{Graciliella n. gen.}

urn:1sid:zoobank.org:act:B0FA4AC2-76D4-42088053-317D44E61E42

Type species: Graciliella apfelbecki apfelbecki (Müller, 1910)

Description. With a body length from 7.09 to $8.63 \mathrm{~mm}$ (HT $8.33 \mathrm{~mm}$ ), this new genus is one of the largestbodied Leptodirini known from the Dinaric Mountains. General morphology leptodiroid; pronotum and mesothoracic pedunculus very elongated, elytra physogastric; eyeless, wingless, and depigmented.

Head. Elongated and hypognathous, wider in the anterior part and wider than the pronotum, HL 1.33$1.58 \mathrm{~mm}$ (HT $1.55 \mathrm{~mm}$ ), HW 0.75-0.93 mm (HT 0.83 $\mathrm{mm})$. Dorsal surface shiny or matte, with superficial microreticulation visible at $40 \mathrm{x}$ magnification under a stereomicroscope and with sparse and short hairs. Few random punctures present on the dorsal surface of the head and most numerous on the frons. Dorsal side of the occiput bearing two patches of punctures with very short hairs on both sides of the head. Labrum trapezoid with setae longer than on the frons. Maxillae long, both galea and lacinia elongated and with brushes of setae. Maxillary palps with 4 articles; second maxillary palpomere arched and about the same length as the third one; terminal maxillary palpomere is the shortest and conical in shape; mean MP2/MP3: 1.33. The base of the terminal maxillary palpomere with a dorsal comb of very short bristles (Fig. 6). Labium with trapezoid submentum bearing two long setae. Mandibles angulate in dorsal view, with sharp apex and with 3 or 4 small teeth between the apex and the last big tooth. Antennal insertions are located in the posterior quarter of the length of the head. Antennae longer than the body, second antennomere is the shortest and last one is longer than the penultimate in both sexes. All antennomeres are covered with hairs of medium length, but only antennomeres 7-11 bear up to 8 long, erected setae arranged circularly and symmetrically in apical part (Fig. 7A). Three last antennomeres $(9,10,11)$ bear very short and thin hairs inserted between the hairs of medium length and long apical setae. These short, thin hairs are the most numerous on the last antennomere where they form dense covering (Fig. 7B).

Pronotum. Distinctly longer than wide, narrow, and with a strong constriction in the posterior quarter. Maximal width is in the second third of its length; $\mathrm{Pw}$ max: 0.6-0.8 mm (HT 0.72 mm); Pwmin: 0.3-0.45 mm (HT 0.36); PL: 1.77-2.27 mm (HT 2.18). Sides divergent in the anterior part of the pronotum, before its maximal width and convergent in the posterior quarter of the length of the pronotum. Surface shiny or matte, with evident microreticulation visible at $40 \mathrm{x}$ magnification under a stereomicroscope. Without or with few very short hairs, mostly in the posterior part.

Mesothoracic pedunculus. Elongated, PL/MPI: 4-5.3 mm (HT 5.06); slightly wider (minimal width) than long or as long as wide; minimal width in the anterior part; MPl: 0.31-0.48 mm (HT 0.43), MPwmin: 0.42-0.55 mm (HT 0.51). Ecusson (scutum+scutellum; Jeannel, 1911) rough, 'U'-shaped and with microsculptural mesh resembling honeycomb pattern.

Elytra. Elliptic, physogastric, and wide; maximum width in the anterior part of the mid-section, at the mid-section, or slightly posterior of the mid-section, EL: 3.48-4.54 mm (HT 4.16), EW: 2.19-3.42 (HT 2.78). Surface smooth, shiny or matte, generally with no microreticulation except in some specimens of Graciliella ozimeci sp. n. Punctuation superficial, spaced, and irregular; if present, hairs are sparse, short or long.

Abdomen. Transversal carina on the posterior margin of mesoventrum non-interrupted, without mesoventral processus; mesocoxal cavities widely confluent (Fig. 8B). Abdominal ventrites densely covered with short hairs except in the anterior part where they are smooth.

Legs. Long, slender, and pubescent. Femora enlarged in the basal parts, tibiae straight or slightly curved inwards (protibiae). Male protarsi with five protarsomeres, female protarsi with four protarsomeres, mesotarsi and metatarsi with five tarsomeres in both sexes. Tarsi not dilated, tarsal empodium with two long setae. 


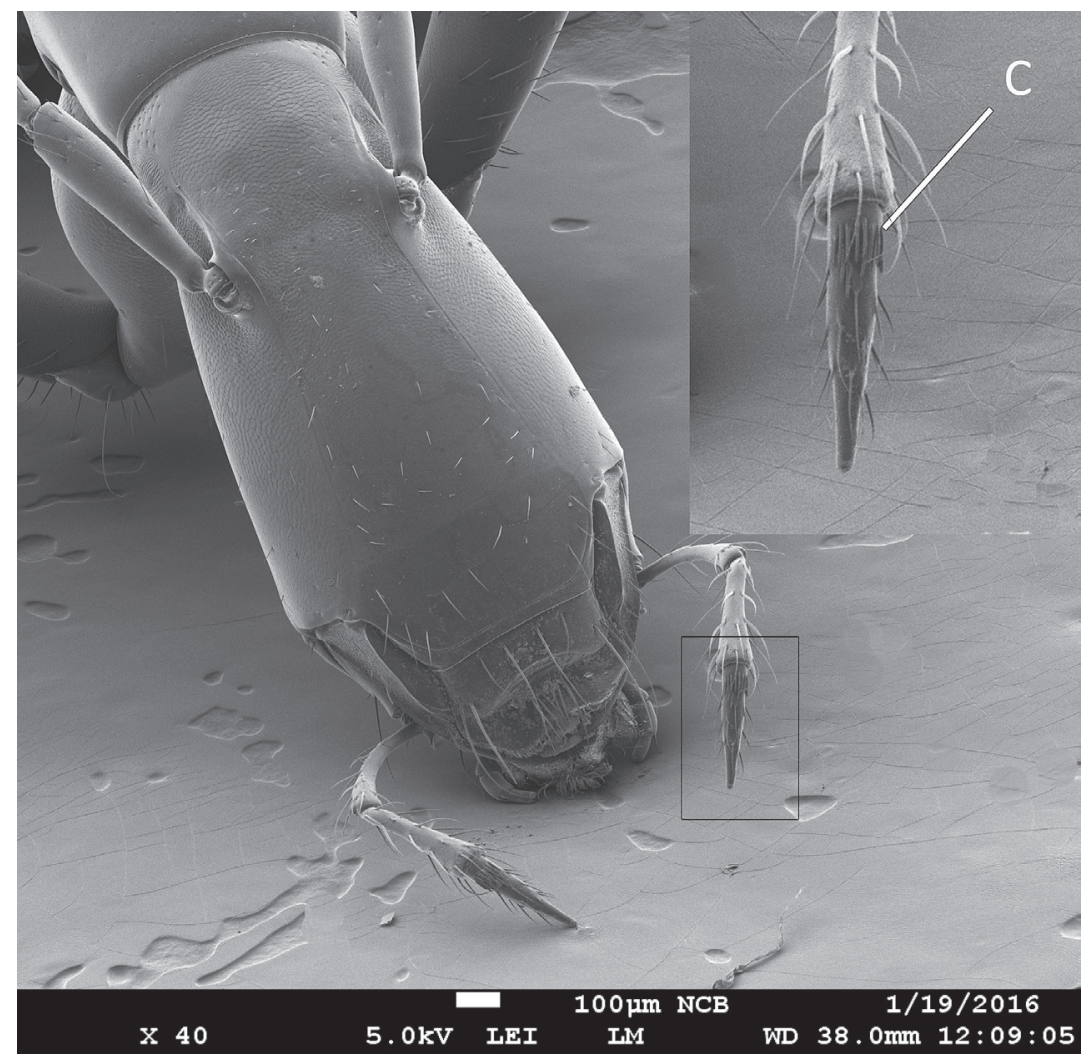

Fig. 6. Terminal maxillary palpomere with a dorsal comb of bristles (c).
Aedeagus (Fig. 2A-J, L, M). Slender, median lobe with rounded, lanceolate or acute apex, endophallus without 'sclerified stylet-shaped phanera in the median part' (Giachino et al., 2011) i.e., endophallus without sclerotized structures. Parameres as long as or shorter than the median lobe (setae excluded), bearing three apical setae. Urite IX reduced to a ring, as in most Leptodirini.

Female genitalia. Abdominal ventrite VIII with a long and narrow anterior expansion. Appendicular parts (gonocoxites and gonosubcoxites, cf. Deuve, 2001 for terminology) of the urite IX absent. Spermatheca: weakly sclerified, 'J'-shaped, short and slightly widened in the apical region (Fig. 2K).

The genus comprises the following taxa that were previously placed in 'hoermanni' species group of the genus Anthroherpon:

Graciliella absoloni (Guéorguiev, 1990) n. comb. Graciliella apfelbecki apfelbecki (Müller, 1910) n. comb.

Graciliella apfelbecki scutulatum (Giachino and Guéorguiev, 1993) n. comb.
Graciliella apfelbecki schwienbacheri (Giachino and Vailati, 2005) n. comb.

Graciliella apfelbecki sculptifrons (Winkler, 1925) n. comb.

Graciliella lahneri (Matcha, 1916) n. comb., n. stat Graciliella metohijensis (Zariquiey, 1927) n. comb., n. stat Graciliella kosovaci sp. $\mathrm{n}$. Graciliella ozimeci sp. n.

After removing these taxa, the 'hoermanni' species group comprises: Anthroherpon hoermanni hoermanni (Apfelbeck, 1889), A. hoermanni hoffmanni Giachino and Guéorguiev, 1993, A. hoermanni hypsophilum Apfelbeck, 1907, A. hoermanni orlovacensis, Guéorguiev, 1990, A. hoermanni sericeum Jeannel, 1930, A. scutariensis Giachino and Guéorguiev, 1993.

Cross diagnosis. The new genus can be easily distinguished from the genus Anthroherpon, even with the naked eye, by the very elongated mesothoracic pedunculus, narrowest in the anterior part, shape of pronotum (Fig. 3) and more spherical-shaped elytra. Additional difference is in the mesoventral processus which 
is absent in Graciliella and present in Anthroherpon (Fig. 8). It differs from the genus Leptomeson by the following combination of characters: larger body size (from 7.09 to $8.63 \mathrm{~mm}$ in Graciliella and from 4.63 to $7.22 \mathrm{~mm}$ in Leptomeson), shape of mesothoracic pedunculus and elongated male genitalia without sclerotized structures in the endophallus (Fig. 2A-J, L, M). In Graciliella, the narrowest part of the mesothoracic pedunculus is in the anterior part while in Leptomeson it is in the mid-section or posterior of the mid-section (Fig. 3).

Distribution. The distribution areas are shown on the map of Fig. 9.

Etymology. The new generic name derives from the Latin word 'gracilis' which means slender and refers to the habitus of the genus.

\section{Identification key to separate genera}

The following identification key of the genera of the subtribe Anthroherponina modifies and updates the respective section of the key given by Perreau and Pavićević (2008):

8. Pronotum and mesothoracic pedunculus less elongated. Mesothoracic pedunculus short or absent; PL/MPl > $5.3 \mathrm{~mm}$ (Fig. 3B). Transversal carina on the posterior margin of mesoventrum interrupted, mesoventrum with long processus between mesocoxae (there is an exception; see: Discussion) (Fig. $8 \mathrm{~A})$ Anthroherpon Reitter

- Pronotum and mesothoracic pedunculus very elongated. Mesothoracic pedunculus long, always

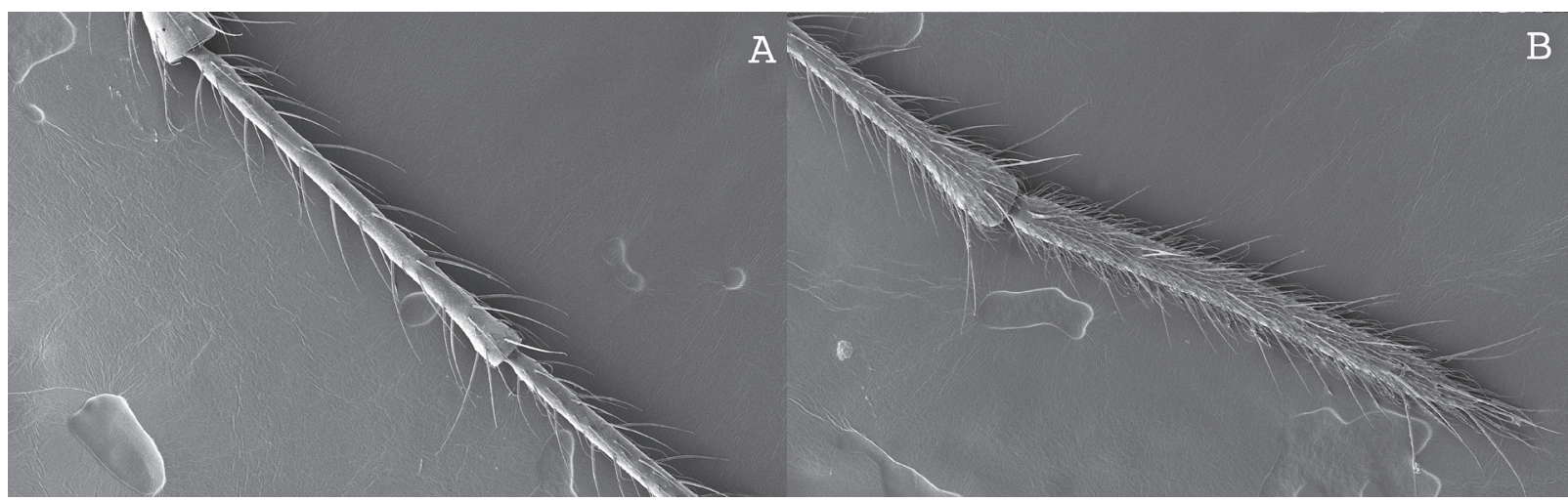

Fig. 7. Antennomeres: A. antennomeres 7 and 8; B. antennomeres 10 and 11.

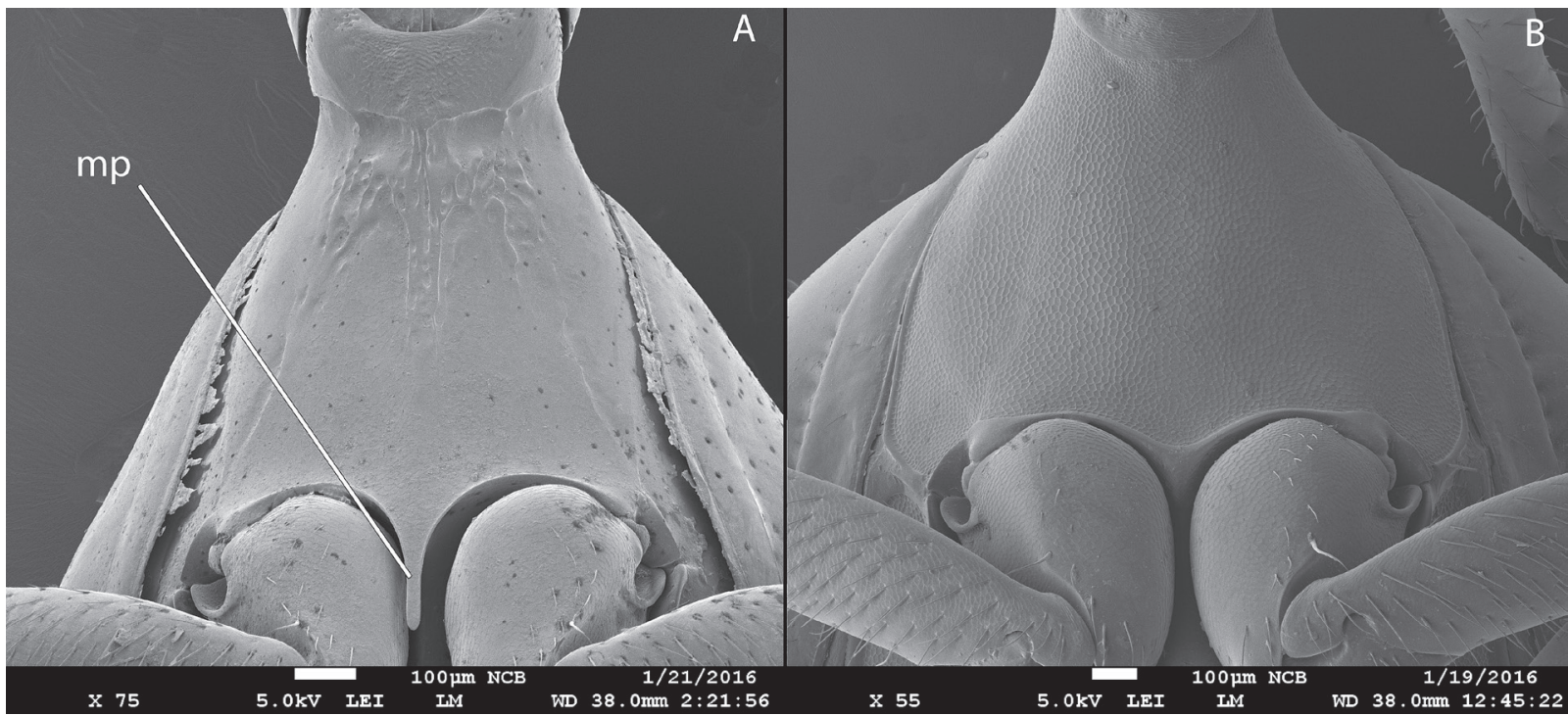

Fig. 8. Mesoventrum of Anthroherpon and Graciliella: A. Anthroherpon cylindricolle cylindricolle, B. Graciliella metohijensis; mp. mesoventral processus. 
present; PL/MPl $<5.3 \mathrm{~mm}$. Transversal carina on the posterior margin of mesoventrum non-interrupted, mesoventrum without processus between mesocoxae 9

9. Mesothoracic pedunculus narrowest in the anterior part (Fig. 3A). Aedeagus slender, without sclerotized structures in the endophallus, parameres bearing 3 setae, (Fig. 2A-J, L, M), body size from 7.09 to $8.63 \mathrm{~mm}$ Graciliella n. gen.

- Mesothoracic pedunculus narrowest in the midsection or posterior of the mid-section (Fig. 3C). Aedeagus robust, with sclerotized structures in the endophallus, parameres bearing 3 or 4 setae, (Fig. $2 \mathrm{~N}, \mathrm{O})$, body size from 4.63 to $7.22 \mathrm{~mm}$

Leptomeson Jeannel

\section{Graciliella kosovaci sp. n.}

urn:Isid:zoobank .org:act:CCB91AA9-E5D4-4DCE9070-C5A3A89C2BFB

Type series. Holotype male labeled as follows: 'CROATIA, Popovići, Gruda, Konavle, Kaverna 781, 50 m, 09.11.2014, leg. R. Ozimec' (white label, printed)/ 'HOLOTYPUS Graciliella kosovaci sp. n. I. Njunjić, M. Perreau, K. Hendriks, M. Schilthuizen and L. Deharveng det. 2015' (red label, printed), (CNHM). Paratype: 19, 09.11.2014, same cave, leg. R. Ozimec,
(CNHM). Paratype is labeled with white, printed locality labels and with red printed labels 'PARATYPUS Graciliella kosovaci sp. n. I. Njunjić, M. Perreau, K. Hendriks, M. Schilthuizen and L. Deharveng det. 2015'. Type locality. Croatia, Popovići, Gruda, Konavle, Kaverna 781, 50 m a.s.1.

Diagnosis. Habitus illustrated in Fig. 10A. Distinct from the other species of the genus by the following characters: small size of the body $(7.09-7.36 \mathrm{~mm})$; lateral sides of pronotum slightly concave in the anterior part before the maximal width; lateral sides of the mesothoracic pedunculus almost parallel on the anterior third of its length; long hairs on the dorsal surface of the elytra; aedeagus small, median lobe with acute apex, parameres strongly arched inwards, of uniform width, bearing very short setae (Fig. 2G, H).

Description. Body length from 7.09 to $7.36 \mathrm{~mm}$ (HT 7.09). General morphology leptodiroid; head wider than pronotum; eyeless; elytra physogastric; wingless, and depigmented.

Head. hypognathous, wider in the anterior part and wider than the pronotum, HL 1.34-1.39 mm (HT 1.39 $\mathrm{mm}$ ), HW 0.75-0.78 mm (HT $0.78 \mathrm{~mm}$ ). Surface smooth and shiny with superficial microreticulation and with sparse and short hairs. Few random punctures present on clypeus and along both sides of fronto-genal sulcus.

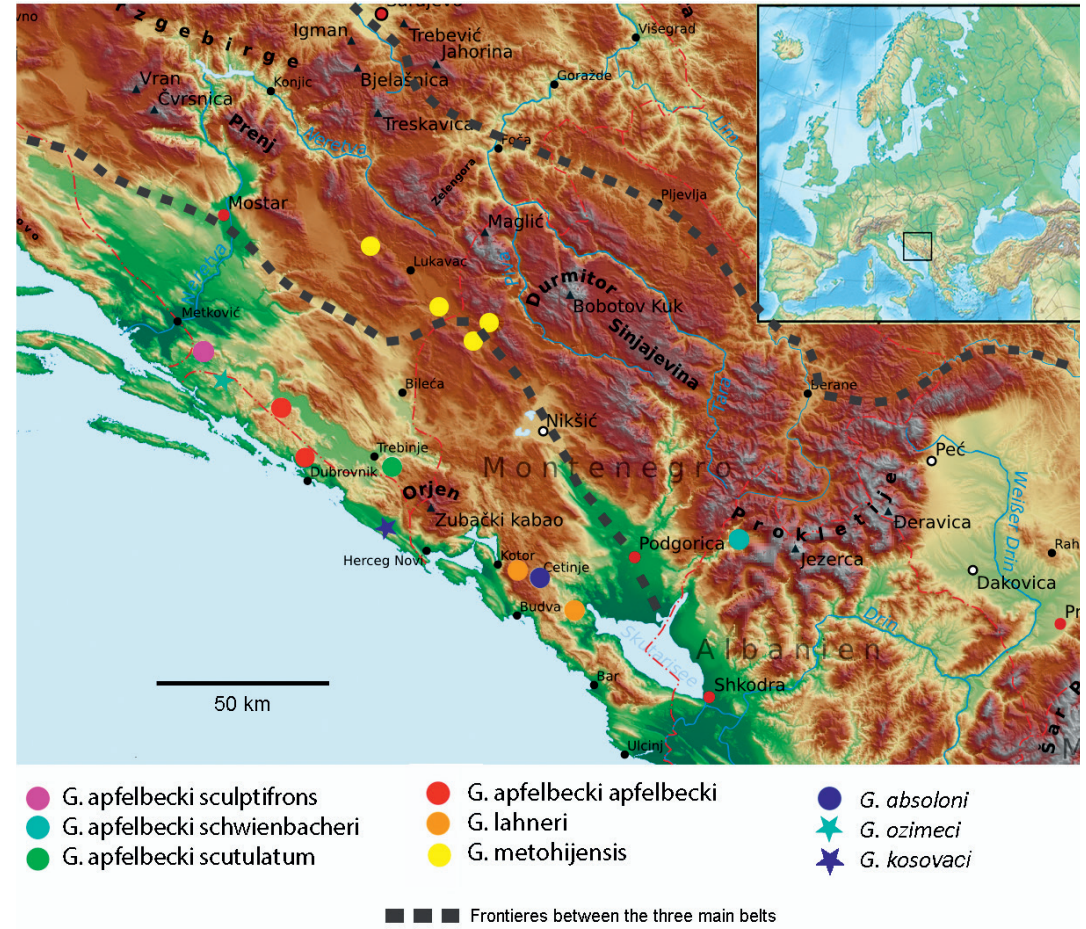

Fig. 9. Distribution map of the species of Graciliella in relation to the main geomorphological units of the Dinaric Mountains. Dotted lines separate the three main belts, from south to north: Maritime Belt or Southwestern Belt, the Central Belt or High Dinaric Mountains, and the Northeastern Belt. 
Table 3. Antennal formula of the holotype of Graciliella kosovaci sp. n.

\begin{tabular}{llllllllllll}
\hline Article & I & II & III & IV & V & VI & VII & VIII & IX & X & XI \\
\hline Length (mm) & 0.47 & 0.30 & 1.02 & 0.86 & 1.21 & 1.08 & 1.00 & 0.79 & 0.88 & 0.75 & 1.03 \\
\hline
\end{tabular}

Table 4. Antennal formula of the holotype of Graciliella ozimeci sp. n.

\begin{tabular}{llllllllllll}
\hline Article & I & II & III & IV & V & VI & VII & VIII & IX & X & XI \\
\hline Length (mm) & 0.51 & 0.37 & 1.00 & 0.92 & 1.28 & 1.11 & 1.07 & 0.85 & 0.93 & 0.76 & 1.06 \\
\hline
\end{tabular}

Pronotum. Narrow and elongated, approximately three times longer than wide, mean PL/Pwmax 3.06 (HT 3.11). Sides divergent and slightly concave in the anterior part before the maximal width, and convergent between the maximal and minimal width of the pronotum. After the minimal width of pronotum, sides are divergent and with rounded posterior margin. Dorsal surface shiny, with superficial microreticulation, and numerous, random and shallow punctures; hairs are not present.

Mesothoracic pedunculus. 1.16 times (HT 1.09) wider than long; lateral sides parallel in the anterior third of the length (measured from the posterior margin of pronotum to the posterior margin of écusson). Ecusson rough, 'U'-shaped and with microsculptural mesh resembling honeycomb pattern.

Elytra. Physogastric and thick in lateral view, maximal width slightly posterior of the mid-section; mean EL/EW: $1.45 \mathrm{~mm}$ (HT 1.52). Surface smooth and shiny, microreticulation not visible; punctuation sparse and superficial. Hairs, sparse and present mostly on the dorsal surface, very rare laterally; as long as the medium-sized hairs on the antennae.

Legs. Like in other species of this genus (see genus diagnosis), protibia straight.

Aedeagus. Small, median lobe longer than parameres (setae included) and with acute apex in dorsal view (Fig. 2G, H). Parameres strongly arched inwards, of uniform width and bearing three short apical setae.

Distribution. Known only from the type locality (Fig. 9). Kaverna 781 is $142 \mathrm{~m}$ long and located in south Croatia, in the tunnel 'Konavosko polje-Sea' and is probably a part of the upper floor system of underground channels which naturally drain the water of Konavle polje to the sea. Lack of stalactite deposits indicates that the cave is a relatively young foundation, and the remains of the freshwater cave-dwelling tube worm Marifugia clavatica observed on the rock indicates its recent hydrological activity (Cvitanović, 2015).

Etymology. We are glad to dedicate this interesting species to a dear friend, speleologist Petar Kosovac from Belgrade, in recognition for his enthusiastic help in the field and in collecting material.

\section{Graciliella ozimeci sp. n.}

urn:lsid:zoobank.org:act:37DB2F08-D301-4637-9023 -E948491ABEAA

Type series. Holotype male labeled as follows: 'CROATIA, Dubrovačko primorje, Točionik, Vranja peć, 230 m, 08.11.2014., leg. R. Ozimec' (white label, printed)/ 'HOLOTYPUS Graciliella ozimeci sp. n. I. Njunjić, M. Perreau, K. Hendriks, M. Schilthuizen and L. Deharveng det. 2015' (red label, printed), (CNHM). Paratypes: 27 $\widehat{\text { }} 30$ \%, 08.11 .2014 , same cave, leg. R. Ozimec, (CNHM, MNHN, CINJ, CMPR, Naturalis). Paratypes are labeled with white, printed locality labels and with red printed labels 'PARATYPUS Graciliella ozimeci sp. n. I. Njunjić, M. Perreau, K. Hendriks, M. Schilthuizen and L. Deharveng det. 2015'. Type locality. Croatia, Dubrovačko primorje, Točionik, Vranja peć, $230 \mathrm{~m}$ a.s.l.

Diagnosis. Habitus illustrated in Fig. 10B. Distinct from the other species of the genus by the following characters: body size 7.13-7.5 mm; elytra more elongated, EL/EW: 1.47-1.64 mm; shorter mesothoracic pedunculus (1.38 times wider than long); surface of the body matte. Aedeagus with rounded apex in dorsal view and almost straight parameres.

Description. Body length from 7.13 to $7.50 \mathrm{~mm}$ (HT 7.45). General morphology leptodiroid; head 


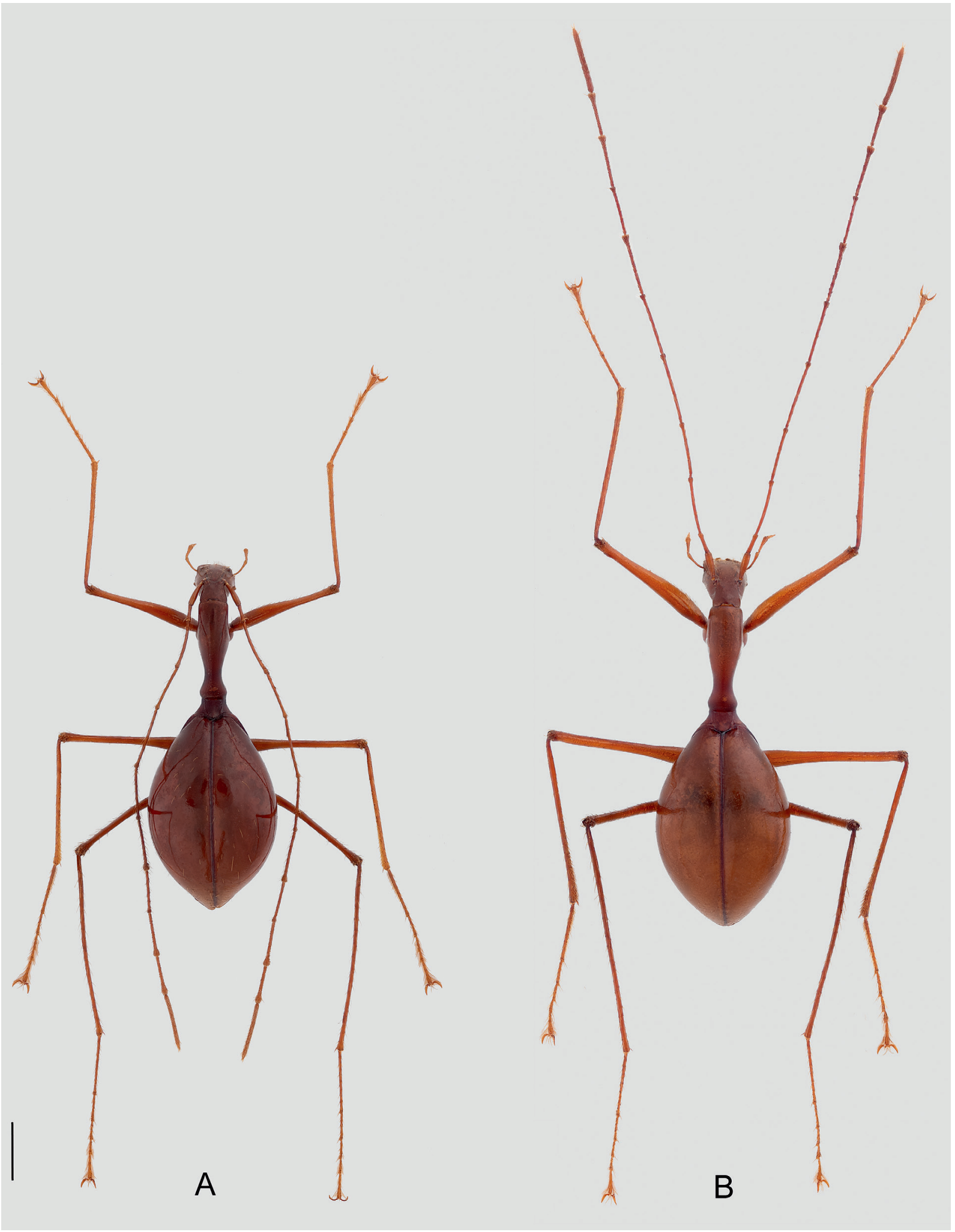

Fig. 10. Habitus of Graciliella. A. G. kosovaci sp. n.; B. G. ozmeci sp. n. Scale bar is $1 \mathrm{~mm}$ (photos by: Theodoor Hijerman). 
wider than pronotum; eyeless; elytra physogastric; wingless, and depigmented.

Head. Hypognathous, wider in the anterior part and wider than pronotum, HL 1.35-1.46 mm (HT 1.46 $\mathrm{mm}$ ), HW 0.75-0.81 mm (HT $0.81 \mathrm{~mm}$ ). Surface matte, with superficial microreticulation and with sparse and short hairs on clypeus, genae, and frons, particularly along the dorsal side of fronto-genal sulcus. Last antennomere is shorter in females.

Pronotum. Narrow and elongated, mean PL/Pw$\max 2.85$ (HT 3.01). Sides almost straight in the anterior part before the maximal width; posterior margin almost straight. Dorsal surface matte and hairless, with superficial microreticulation, and numerous, random and shallow punctures. Ventral side of the pronotum completely smooth behind the first pair of legs.

Mesothoracic pedunculus. 1.38 times (HT 1.53) wider than long; lateral sides parallel in the anterior quarter of the length (measured from the posterior margin of pronotum to the posterior margin of écusson). Ecusson rough, 'U'-shaped and with microsculptural mesh resembling honeycomb pattern.

Elytra. Physogastric but narrow; maximal width slightly posterior of the mid-section; mean EL/EW: 1.47-1.64 mm (HT 1.49). Surface irregular and matte, microreticulation and punctures visible in some specimens. Hairs very sparse and present mostly on the dorsal surface, very rare or absent laterally.

Legs. Like in other species of the genus (see genus description), protibia straight.

Aedeagus. Median lobe longer than parameres (setae excluded) and with rounded apex in dorsal view (Fig. 2I, J). Parameres almost straight, of uniform width and bearing three apical setae.

Distribution. Known only from the type locality (Fig. 9). Vranja peć is situated in south Croatia, in the municipality Dubrovačko primorje, close to the village Točionik. It is a cave with a vertical entrance, $188 \mathrm{~m}$ long and $50 \mathrm{~m}$ deep. The bottom of the channel is covered with rock debris and large blocks of rocks broken off from the ceiling. The cave is hydrologically inactive except the small drippings at the bottom (Cvitanović, 2015).

\section{Graciliella apfelbecki apfelbecki (Müller, 1910) n. comb.}

Antroherpon apfelbecki Müller, 1910: 186.

Type locality. Höhle zwischen Jasenica und Zavala (Herzegowina) [= pećina Vjetrenica; N $42^{\circ} 50^{\prime} 28.34$ "' E $17^{\circ} 59^{\prime} 11.87^{\prime}$, alt. $\left.268 \mathrm{~m}\right]$
Antroherpon Apfelbecki J. Müller: Jeannel, 1911: 560. Antroherpon (s. str.) Apfelbecki J. Müller, 1910: Jeannel, 1924: 420.

Antroherpon Apfelbecki Müll: Winkler, 1925: 144.

Antroherpon (s. str.) Apfelbecki subsp. Apfelbecki Müller: Jeannel, 1930: 147.

Antroherpon apfelbecki J. Müller: V.B. Guéorguiev, 1990: 264.

Antroherpon apfelbecki apfelbecki J. Müller, 1910: Giachino and Guéorguiev, 1993: 316.

Antroherpon apfelbecki J. Müller: Perreau and Pavićević, 2008: 211.

Antroherpon Kauti Apfelbeck, 1911: 216. (synonymy in Jeannel, 1914).

Type locality: Herzegowina: in der Vjeternica höhle bei Zavala.

Antroherpon Kauti Apfelbeck, 1916: 346.

Material examined. 10: LECTOTYPE (here designated), Hercegovina, 'Vjeternica H.', 11.07.1914., leg. K. Absolon, RMNH.INS.627472 (Naturalis); 19: PARALECTOTYPE (here designated), Herzegovina Vjeternica, 1931, leg. K. Absolon (MNHN); 10: COTYPE, Höhle bei Savala, Herzegovina (MNHN); 10, 1요 Herzegovina Vjeternica, leg. K. Absolon (MNHN); 1ㅇ: Zavala, Hr., leg. Novak, 5.9.1925 (MNHN); 19: Zavala, Herzeg. (MNHN); 10: Hercegovina, Neretva, Ravno, Zavala, Vjeternica pećina, Popovo polje, 42.88-17.98 03/ VI/2011., leg. M. Perreau, RMHN.INS.550268 (Naturalis); 1: same data, RMNH.INS.550269 (Naturalis); 19: Vjeternica pećina, Collectie G. Paganetti-Hummler acq. 1937, ZMA.INS.1236005 (Naturalis); 19: same data, ZMA.INS.1236007 (Naturalis); 10: Hercegovina, Zavala, Dr. Grabowski, Coll. Dr. S. Breuning, ZMA. INS.1235988 (Naturalis); 2\%: BiH, Zavala, Vjeternica., leg. R. Ozimec (CNHM); 19: same locality, 21.08.2008., leg. Bakšić Darko (CNHM); 20: same locality, 20.08.2007., leg. M. Perreau (CMPR); 19: Zavala, Popovo polje, Vjetrenica, Hercegovina, 12.09.1975., leg. Pretner (CMPR); 19: Dr. Absolon, Vjeternica (CMPR); 10 : Vjeternica, Absolon, 1912, Hercegovina (CMPR); 19: Kali pecina apud Grebci, Herzegovina, Absolon (CMPR); 3 ? : Grabovica bei Grepci, Herzegovina, Absolon (CMPR); 30 3 3 : Gjurkovina pećina apud Grepci, Herzegovina, Absolon (CMPR); $2 \hat{0} 4$ ㅇ: Močiljska pec, Rjeka-Dubrov., Svircev, 5.1.931. (MNHN); $10^{\star}$ 1요 Močiljska pec. Dubrovnik, Svircev, 1.9.923. (MNHN); 20: Croatia, Dubrovačko primorje, Dubrovnik, Osojnik, Močiljska špilja, 12.11.2014., leg. Hanžek Nikola (CNHM); 2ᄋ: same locality, leg., R. Ozimec (CNHM); 19: Močiljska pećina, Močilje, Ombla, Dalmatia, leg. E. 
Pretner (CMPR); 10ิ: Croatia, Dubrovačko primorje, Dubrovnik, Gromača, Špilja za Gromačkom vlakom, 28.08.2014., leg. Slapnik Rajko (CNHM); 19: same locality, 25.09.2014., leg. Slapnik Rajko (CNHM); 1: Bosnia and Herzegovina, Bobani, Grabovica, 08.05.2011., leg. R. Ozimec (CNHM); 1 ' : Grotte Grabovica, Herzegovina Weirather, 1-14 (MNHN); 10: Kali pećina, Grebci, Herceg., Svircev, 2.1.931. (MNHN); 10: Gr. Močilje, pr. Ragusa, 30.11.921., G. Müller (MNHN); 2\%: Orlica pecina, Popovo polje, Herzegovina, Absolon (CMPR); 1: Ravno Hercegov. Vl. Zoufal (CMPR); 10: Bihovo, Trebinje, Herz, Collectie G. Paganetti-Hummler acq. 1937, ZMA.INS.1236013 (Naturalis).

Diagnosis. Habitus illustrated in Fig. 11A. Body length from 7.3 to $8.63 \mathrm{~mm}$. Median lobe with lanceolate apex in dorsal view and considerably longer than parameres (setae excluded). Parameres of uniform width, slightly curved inwards in the apical part and bearing three long apical setae (Fig. 2A, B).

Remarks. Two specimens, one in Naturalis and the other one in MHNH were labelled as types, so we designated the male specimen from Naturalis as lectotype and female specimen from MNHN as paralectotype.

We do not have molecular data for the three following subspecies of G. apfelbecki, so we follow the classification of Giachino and Vailati (2005) on this point.

\section{Graciliella apfelbecki scutulatum (Giachino and} Guéorguiev, 1993) n. comb.

Antroherpon scutulatum Giachino and V.B. Guéorguiev, 1993: 317.

Type locality: Erzegovina, Bravenik [= Hercegovina, Zupci, Bravenik; N 42³7.143’ E 18²5.969’, alt. 740 m a.s.l.]

Antroherpon apfelbecki scutulatum Giachino and Guéorguiev: Perreau and Pavićević, 2008: 212.

Material examined: $10 \hat{\text { 3 }}$ \%: BiH, Trebinje, Zupci, Bravenik (= Jama u Braveniku), alt. $740 \mathrm{~m}$ a.s.l., 19.06.2003., leg. M. Perreau (CMPR).

\section{Graciliella apfelbecki schwienbacheri (Giachino} and Vailati, 2005) n. comb.

Anthroherpon apfelbecki schwienbacheri Giachino and Vailati, 2005: 159.

Type locality: Albania, Kelmend, Tamara umg., Shpella Siper Rruges, $185 \mathrm{~m}$ a.s.l.

Material examined: We did not examine this subspecies.
Graciliella apfelbecki sculptifrons (Winkler, 1925) n. comb.

Antroherpon Apfelbecki sculptifrons Winkler, 1925: 144.

Type locality: In einem Hallenschacht bei der Žaba planina südlich von Metković [=Žaba Mt, Golubinka]

Antroherpon (s. str.) Apfelbecki subsp. sculptifrons Winkler: Jeannel, 1930: 147.

Antroherpon apfelbecki sculptifrons Winkler: Pretner, 1974: 11.

Material examined: 1ठิ: TYPE, Žaba plan., Golubinka (NHM).

Graciliella metohijensis (Zariquiey, 1927) n. stat., n. comb.

Antroherpon Apfelbecki subsp. Metohijensis Zariquiey, 1927: 163.

Type locality: Höhle 216, Urvol P., Nordostherzeg., Karstlande [= Đatlo pećina, Korita, Bosnia and Herzegovina; N 4303.710’ E $18^{\circ} 29.678^{\prime}$, alt. 1013 m a.s.1.]

Antroherpon (s. str.) Apfelbecki subsp. metohiensis Zariquiey: Jeannel, 1930: 147.

Antroherpon apfelbecki metohijense Zariquiey: Pretner, 1974: 11.

Antroherpon apfelbecki metohijensis Zariquiey: Guéorguiev, 1990: 265.

Antroherpon apfelbecki metohijensis Zariquiey, 1928: Giachino and Guéorguiev, 1993, Natura bresciana: 317.

Material examined. 10: TYPE, H 216 Urvol p. Weirather, NordostHerzeg. 1922., Karstlande (MNHN); 10: BiH, Korita, Kobilja Glava, Đatlo, alt. 1013m, 13.09.2006., leg. M. Perreau (CMPR); 19: same locality, 05.08.2013., leg. M. Perreau (CMPR); 1: same locality, 15.03.2008, leg. S. Ognjenović (CMPR); 19: same locality, 13.07.2007., leg. M. Đokić (CMPR); 3 t: same locality, 23.06.2003., leg. M. Perreau (CMPR); 30 3ㅇ: BiH, Korita, Brestica, Jametina, 14.07.2007., leg. M. Perreau (CMPR); 10 $\overbrace{}^{\star} 8$ : BiH, Balabani, Drvendžina pećina, 26.08.2013., leg. I. Njunjić (CMPR, CINJ); 3 ô 3ㅇ: Montenegro, Golija Mt, Donje Čarađe, Prljača, 07.08.2010., leg. S. Ognjenović (CDPV); 2 , same locality, 28.08.2010., leg. I. Njunjić (CINJ); 2 , same locality, 13.08.2010, M. Plećaš (CDPV); 10ิ, same locality, same date, leg. M. Perreau (CMPR); 3 ;: Montenegro, Kazanci, Bijela pećina, 10.08.2010, leg., M. Perreau; 1: Hercegovina, grot Provalija, 22.07.1962., RMNH.INS.627543 (Naturalis); 1ㅇ: same 
data, Hercegovina, grot Provalija, 22.07.1962., RMNH. INS.627700 (Naturalis); 10 5\%: Montenegro, Stozi, Stoška pećina, 10.08.2010., leg. I. Njunjić (CINJ); 2 \%: same data, leg. S. Ognjenović (CDPV).

Diagnosis. Habitus illustrated in Fig. 11B. Large species, body length from 7.76 to $8.53 \mathrm{~mm}$. Distinct from the other species of the genus by the following characters: elytra strongly physogastric and very wide, mean EL/EW: 1.33 , with the largest width slightly before the mid-section and dense but shallow punctuation. Sparse hairs are present mostly on the dorsal surface of the elytra. Pronotum with rounded anterior margin. Parameres shorter than the median lobe (setae excluded), with strong constriction in the preapical region (Fig. $2 \mathrm{C}, \mathrm{D})$ in some populations, or without the constriction. Median lobe of the aedeagus with lanceolate apex in dorsal view. This combination of characters supports the change of the status from subspecies to species rank. New status is consistent with the molecular phylogeny, morphometrics and geographic location of this species mostly in the Central Belt of the Dinaric Mountains (Golija Mt., Vojnik Mt., Crvanj Mt., Somina Mt., Korita), rather than in the Southwestern (Maritime) Belt as most of the other species and subspecies of the genus Graciliella.

Remarks. There is inter- and intrapopulation variability in the shape of parameres: In some populations (e.g., Drvendžina pećina in Balabani) the parameres have a strong preapical constriction while in others (e.g., Prljača on Golija Mt., Stoška pećina on Somina Mt.), the parameres are of equal width in full-length. In the population from Drvendžina pećina there is a gradient in this character: from evident preapical constriction to parameres without constriction. Some specimens from this population have asymmetric aedeagi: one paramere with constriction and other without. Since we have sequences from only two specimens from the population of Drvendžina pećina, we are unable to assess the taxonomic significance of this variability.

\section{Graciliella lahneri (Matcha, 1916) n. stat. n. comb} Antroherpon Lahneri Matcha, 1916: 63.

Type locality: Montenegro: Lottspeich Grotte bei Njeguši

Antroherpon (s. str.) Lahneri Matcha, 1916: 420.

Antroherpon Lahneri Matcha: Fagniez, 1927: 23.

Antroherpon (s. str.) Lahneri Matcha: Jeannel, 1930: 147.
Antroherpon apfelbecki lahneri Matcha: Guéorguiev, 1990: 265.

Antroherpon apfelbecki lahneri Matcha, 1916: Giachino and Guéorguiev, 1993: 317.

Material examined. 19: TYPE, Lovćen, Geb. Mal. 1916, Montenegro, Rittm. Matcha, Duboki do (MNHN); 1: Montenegro, Lovćen Mt, Bjeloši, Jankova jama, 27.06.2013., leg. I. Njunjić (CINJ); 20 : Montenegro, Virpazar, Trnovo, Grbočica, 30.05.2004., leg. R. Mlejnek (CMPR); 10̃: Montenegro, Virpazar, Trnovo, Grbočica pećina, cave traps, 21.03-16.07.2008., leg. R. Lohaj, ZMA.INS.1236016 (Naturalis); 1: same data, ZMA.INS.1235992 (Naturalis).

Diagnosis. Elytra slightly convex on the disc. Median lobe of the aedeagus elongated and narrow, with acute apex. Parameres as long as the median lobe, with weak preapical constriction and significantly wider in the apical part. Apex of the parameres acute and bearing three setae (Fig. 2L, M). The distinctive shape of the aedeagus allows the change of the status from subspecies to species rank. New status is consistent with the morphometrics and the geographic location of this species in Mountains of Maritime Montenegro.

Graciliella absoloni (Guéorguiev, 1990) n. comb. Antroherpon absoloni Guéorguiev, 1990: 265.

Type locality: Montenegro, Lipska pećina près de $\mathrm{Ce}$ tinje [N $42^{\circ} 22.433^{\prime}$ E $018^{\circ} 57.207^{\prime}$, alt. $456 \mathrm{~m}$ a.s.l.]

Material examined. 10: TYPE, Montenegro, Lipska pećina près de Cetinje, 10.VIII 1912., leg. J. Matcha (NMP); 1 : PARATYPE, same data (NMP).

Diagnosis. Body length $7.53 \mathrm{~mm}$ (HT). Elongated mesothoracic pedunculus, narrowest in the anterior part, PL/MPl: 4.13 (HT). Pronotum distinctly longer than wide, narrow, and with a strong constriction in the posterior quarter. Maximal width is in the second third of its length; PL: $1.98 \mathrm{~mm}$ (HT). Elytra elliptic and physogastric; EL: $3.5 \mathrm{~mm}$ (HT). Aedeagus slender, endophallus without sclerotized structures, elongated and with lanceolate apex in dorsal view. Parameres shorter than the median lobe, with weak preapical constriction and slightly wider in the apical part, bearing three setae (Fig. 2E, F). These characters fit in the description of Graciliella which allows us to place this species in this new genus. 


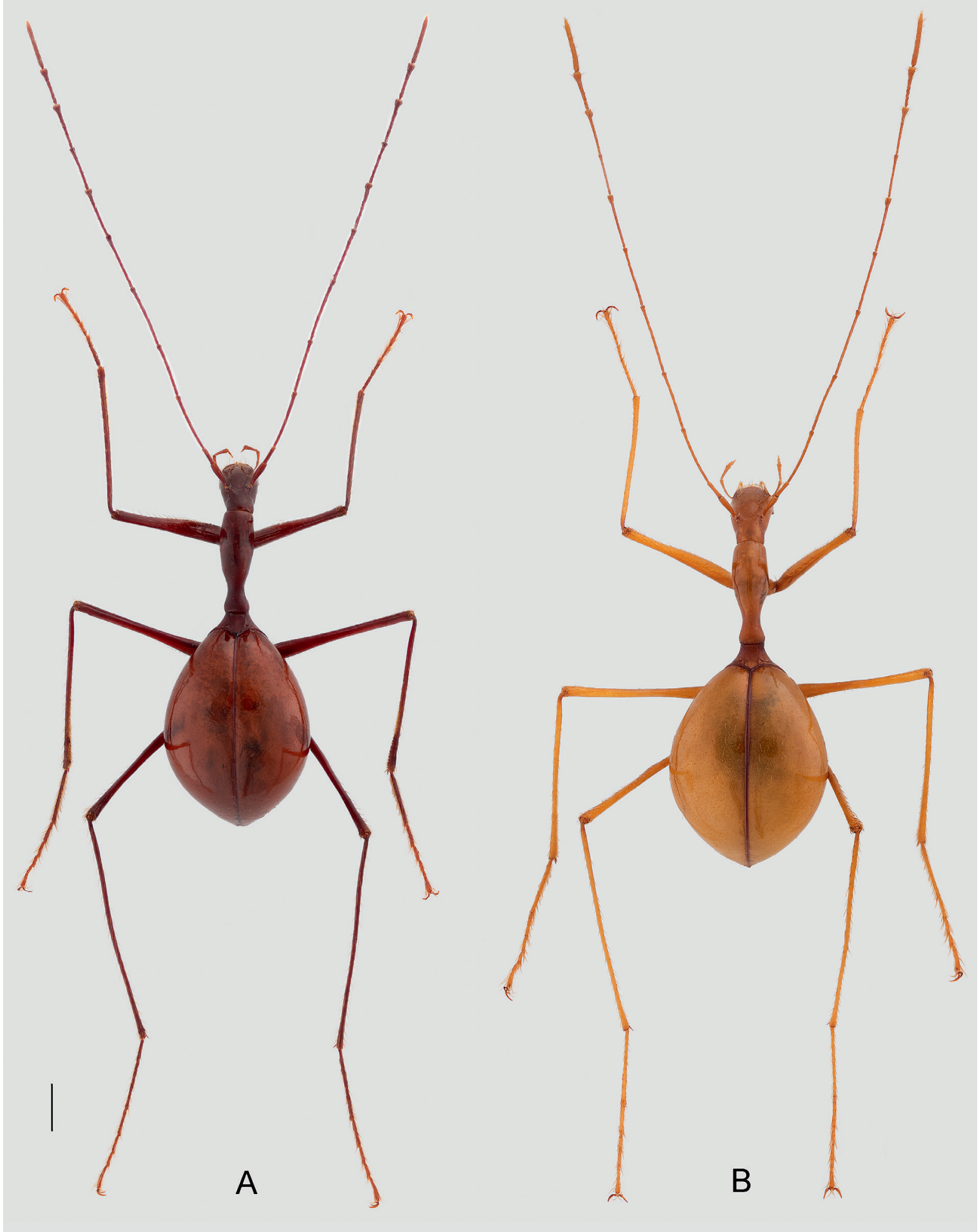

Fig. 11. Habitus of Graciliella. A. G. apfelbecki apfelbecki; B. G. metohijensis. Scale bar is 1 mm (photos by: Theodoor Hijerman). 


\section{Identification key}

Here we present the identification key to the genus Graciliella, excluding the subspecies. It is dedicated to practical identification of species and does not correspond to the molecular phylogeny. Although we have used a few characters previously mentioned in the $A n$ throherpon key of Giachino and Vailati (2005), the present key is based chiefly on the diagnoses provided above.

1. Elytra strongly physogastric and very wide, EL/ EW: $1.18-1.43 \mathrm{~mm}$, with the largest width slightly before the middle, depressed and attenuated towards the apex ..................... metohijensis (Zariquiey) - Elytra less physogastric and less wide, EL/EW: 1.3$1.64 \mathrm{~mm}$, with the largest width in the mid-section or slightly in the posterior part of the mid-section, not depressed and not attenuated towards the apex

2

2. Anterior part of the pronotum ovoid. Parameres as long as the median lobe, significantly wider in the apical part ....................................... lahneri (Matcha)

- Anterior part of the pronotum subcylindrical. Parameres shorter than the median lobe, same width in the full length or slightly wider in the apical part ...

3. Protibiae weakly curved inwards. Elytra with rounded apex and with the largest width in the middle. Parameres with weak preapical constriction and slightly wider in the apical part. (6.7-7.1 mm) . absoloni (Guéorguiev)

- Protibiae straight. Elytra with acute apex and with the largest width slightly posterior of the mid-section. Parameres of uniform width, without constriction in the apical part ... 4

4. Lateral sides of pronotum convex in the anterior part. Median lobe with lanceolate apex in dorsal view and considerably longer than parameres (setae excluded). Parameres of uniform width, slightly curved inwards in the apical part. Body length 7.3$8.63 \mathrm{~mm}$ apfelbecki (Müller)

- Lateral sides of pronotum concave or almost straight in the anterior part. Median lobe with acute apex or rounded in the apical part, longer than parameres (setae excluded). Parameres strongly arched inwards or almost straight. Body length 7.09-7.5 $\mathrm{mm}$ 5

5. Lateral sides of the pronotum concave in the anterior part before the maximal width. Dorsal surface of the body smooth and shiny. Long hairs on the dorsal surface of the elytra. Aedeagus with acute apex in dorsal view, parameres strongly arched inwards, bearing very short setae ........ kosovaci sp.n. - Lateral sides of pronotum almost straight in the anterior part before the maximal width. Dorsal surface of the body matte. Short hairs on the dorsal surface of the elytra. Aedeagus with rounded apex in dorsal view, parameres almost straight, bearing long setae ozimeci sp.n.

\section{Biogeography and ecology}

The genus Graciliella is distributed in subterranean habitats of the Dinaric Mountains, from Crvanj mountain (Bosnia and Herzegovina) in the north, to Trnovo (Montenegro) in the south, and from Žaba mountain (Croatia) in the west to Prokletije mountain (Montenegro) in the east. It is distributed from an altitude of 50 m (G. kosovaci in Croatia, Konavle, Kaverna 781) to $1270 \mathrm{~m}$ (G. metohijensis in Montenegro, Somina, Stoška pećina) above sea level.

Figure 9 shows the geographic distribution of the species of the genus Graciliella, in relation to the three main geomorphological units of the Dinaric Mountains: the Maritime Belt or Southwestern Belt, the Central Belt or High Dinaric Mountains, and the Northeastern Belt (Hajna, 2012). The genus Graciliella is present only in the Maritime and Central Belt. Even though the cave fauna of the Northeastern Belt is fairly well known, Graciliella have never been found in this region. The distribution of $G$. apfelbecki schwienbacheri far from other apfelbecki subspecies and in the Central Belt rather than in the Maritime Belt of the Dinaric Mountains where other apfelbecki subspecies are distributed indicates that the systematic position of this subspecies should be analyzed using molecular approaches.

In the region of Velež Mt. in Bosnia and Herzegovina all three genera were found - Leptomeson loreki Zoufal, 1904, Anthroherpon ganglbaueri ganglbaueri (Apfelbeck, 1894) and Graciliella metohijensis (Zariquiey, 1927), but never in syntopy. However, in a few caves in Bosnia and Herzegovina (e.g. Vjeternica in Zavala, Bravenik in Zupci, Veliko Đatlo in Korita) and Croatia (Špilja za Gromačkom Vlakom in Dubrovačko primorje), Graciliella and Hadesia coexist in the same cave. The biotope of Hadesia differs in many aspects from most other troglobitic species of Leptodirini - these beetles inhabit a semi-aquatic cave habitat called 'hygropetric' - they are always found in the vicinity of strong flows of running water 
on stalagmitic walls and often inside the film of running water (Jeannel, 1924, Remy, 1940, Sket, 2004, Perreau and Pavićević, 2008). Graciliella, Anthroherpon and Leptomeson, however, prefer cave walls without water flow and they have never been found inside the water film itself. Also, they have never been observed on deposits of guano and almost never under the rocks on the cave floor. The representatives of these three genera inhabit humid cave walls, stalac- tites and stalagmites with almost no visible siltation. Their diet is understudied but it is assumed that they are saprophagous like many other Cholevinae (Beutel and Leschen, 2016) while Hadesia is considered to filter water or brush the surface of stalagmitic walls with its specialized mouthparts (Perreau and Pavićević, 2008). The different ecological niches in Hadesia and Graciliella may allow coexistence without competition. 